\title{
THE NEW LACHES: CREATING TITLE WHERE NONE EXISTED
}

\author{
Kathryn E. Fort
}

\begin{abstract}
"Laches can scarcely create title where none existed."
"A thousand years in the sight of the Chancellor are but as yesterday."2 "[In] a suit brought by the United States in its sovereign capacity ..., it is clear state limitations period[s] do not apply."
\end{abstract}

\section{INTRODUCTION}

Recent legal decisions dealing with Indian land claims have been creating title for private property owners where no title previously existed. As has been explored by others, various areas of property law have been turned upside down in order to defeat tribes in court. ${ }^{4}$ However, one area, equity, has received special attention from the courts. ${ }^{5}$ Specifically, the equitable defenses of laches, acquiescence, and impossibility were used by the United States Supreme Court in City of Sherrill v. Oneida Indian Nation ${ }^{6}$ to hand defeat to the Oneida Indian Nation on a tax issue. ${ }^{7}$ Since then, lower courts in the Second Circuit have used this precedent to deny Indian land claims altogether. ${ }^{8}$ But is the use of these three defenses based on precedent themselves? A careful examination of City of Sherrill and its progeny reveals that these defenses have in fact been combined to create a new defense,

* Staff Attorney, Michigan State University Indigenous Law and Policy Center; Adjunct Professor, Michigan State University College of Law; B.A., Hollins College, 1999; J.D., Michigan State University College of Law, 2005. I would like to thank Matthew L.M. Fletcher, Wenona T. Singel, Carrie Garrow, Bryan Newland, Joy Grow, Michelle Bostic, and Jane Edwards, Barbara Bean, and the rest of the MSU College of Law library staff. I would like to especially thank Ross and David Fort, and Diane, Ken, and Anne Henningfeld.

1 Ziegler v. Simmons, 91 N.W.2d 819, 823 (Mich. 1958).

2 George Wharton Pepper, The Effect of Lapse of Time on Suits in Equity, 41 AM. L. REG. \& REV. 319, 331 (1893).

3 Occidental Life Ins. Co. v. EEOC, 432 U.S. 355, 378 (1977) (Rehnquist, J., dissenting) (citing Bd. of Comm'rs v. United States, 308 U.S. 343, 351 (1939)).

4 See Joseph William Singer, Nine-Tenths of the Law: Title, Possession \& Sacred Obligations, 38 CONN. L. REV. 605, 610 (2006).

5 See, e.g., City of Sherrill v. Oneida Indian Nation, 544 U.S. 197 (2005); Ewart v. Bluejacket, 259 U.S. 129 (1922); Cayuga Indian Nation v. Pataki, 413 F.3d 266 (2d Cir. 2005), Swim v. Bergland, 696 F.2d 712 (9th Cir. 1983).

6544 U.S. 197 (2005).

7 Id. at 202-03, 217-21.

8 See infra note 52 and accompanying text. 
what I will call the "new laches" defense. This new defense, so far used successfully in Indian land cases in New York State ${ }^{9}$ but unsuccessfully elsewhere, ${ }^{10}$ has been so broadly construed by the Second Circuit that it could apply to any treaty-based claim brought by Indians or Indian tribes. ${ }^{11}$ If this interpretation were adopted nationwide, it could be used by federal, state, and local authorities to quash any Indian land claim.

Laches is rarely used outside of some narrow areas of common law ${ }^{12}$ and has been all but barred from federal Indian law cases. ${ }^{13}$ The Supreme Court's decision in City of Sherrill, however, injected this new equitable

9 See infra note 52 and accompanying text.

10 Paiute-Shoshone Indians v. City of Los Angeles, No. 1:06-cv-00736 OWW LJO, 2007 WL 521403 , at *8 (E.D. Cal. Feb. 15, 2007) ("Here, however, because the issue of laches raises significant questions of fact that cannot be resolved on a motion to dismiss, it is most efficient to deny they [sic] City's motion to dismiss on the ground of laches, without prejudice to its renewal."). The court goes on to discuss and cite to City of Sherrill. Id. at *9-11.

11 Mem. of Law in Supp. of the State of N.Y. Defs.' Mot. to Dismiss at 17, Onondaga Nation v. New York, No. 05-CV-00314 (N.D.N.Y. Aug. 15, 2006) ("Aboriginal land claims that have a disruptive effect on the governance of state and local jurisdictions and upon the long-settled, justifiable expectations of current landowners are subject to dismissal, on a motion to dismiss, based upon well-recognized equitable principles."). The state does not limit its conclusion to land claims based on the NonIntercourse Act, which it could, given it is fighting a claim based on violation of the Non-Intercourse Act. Id. at 2, 17. Instead it chose to follow the broader view of Cayuga Indian Nation v. Pataki, 413 F.3d 266 (2d Cir. 2005), that Sherrill's holding applies to any aboriginal land claim that may be considered disruptive. Id. at 20.

12 See, e.g., Boone v. Mech. Specialties Co., 609 F.2d 956, 958 (9th Cir. 1979) (Title VII claim); Oliver v. State, 843 N.E.2d 581, 586-88, 592 (Ind. Ct. App. 2006) (post-conviction petition).

13 Bd. of Comm'rs v. United States, 308 U.S. 343, 351 (1939) ("'[S]tate notions of laches and state statutes of limitations have no applicability to suits by the Government, whether on behalf of Indians or otherwise." (citing United States v. Minnesota, 270 U.S. 181 (1926))); Ewart v. Bluejacket, 259 U.S. 129,138 (1922) ("[T] he equitable doctrine of laches . . cannot properly have application to give vitality to a void deed and to bar the rights of Indian wards in lands subject to statutory restrictions." (citing Northern Pac. Ry. Co. v. Boyd, 228 U.S. 482, 500 (1913); Halstead v. Grinnan, 152 U.S. 412, 417 (1894); Galliher v. Cadwell, 145 U.S. 368, 372 (1892))); Swim v. Bergland, 696 F.2d 712, 718 (9th Cir. 1983) ("Laches or estoppel is not available to defeat Indian treaty rights. This is true even where the Indians have long acquiesced in use by others of affected lands or have purported to grant away their occupancy and use rights without federal authorization." (citations omitted)); United States v. 7,405.3 Acres of Land, 97 F.2d 417, 423 (4th Cir. 1938) ("It is beyond the power of the state, either through statutes of limitation or adverse possession, to affect the interest of the United States; and the United States manifestly has an interest in preserving the property of these wards of the government for their use and benefit."); Canadian St. Regis Band of Mohawk Indians v. New York, 278 F. Supp. 2d 313, 330-33 (N.D.N.Y. 2003) (chastising the state defendants for continuing to argue laches against the tribe's claims because "[I] aches has no place in Indian land claim actions"); Schaghticoke Tribe of Indians v. Kent Sch. Corp., 423 F. Supp. 780, 784-85 (D. Conn. 1976) ("The cases make plain that limitations, adverse possession, laches and estoppel cannot bar recovery of Indian lands in a suit brought to recover protected territory. ... [T] he inapplicability of these affirmative defenses extends to suits by individual Indians and is not solely a product of the sovereign immunity of the United States. The determination is rooted in the language and purpose of federal protective statutes like the Nonintercourse [sic] Act." (footnote omitted)). 
defense into the area of federal Indian law, allowing state and local government defendants to eliminate land claims before they begin. ${ }^{14}$ Furthermore, the broad reading of the new laches defense by the Second Circuit enables states and others opposing tribal claims to use this argument against any tribal treaty claim based on so-called "ancient" 15 transactions and treaties. ${ }^{16}$

In addition to laches, the City of Sherrill Court analyzed two other equitable defenses, acquiescence and impossibility, ${ }^{17}$ but lower courts have focused almost exclusively on laches. ${ }^{18}$ However, it would be more accurate to identify this version of laches as a new defense, distinguishable from the traditional laches defense. This "new laches" was created from a combination and misunderstanding of laches, acquiescence, and impossibility and seems to be applicable only against Indian claims. ${ }^{19}$ Rather than being based primarily upon the length of time from the original wrong to its arrival in federal court, the new laches defense is based upon the disruption a successful claim may cause to the "settled expectations" of state and local government defendants. ${ }^{20}$ It is not clear what character of disruption is nec-

14 City of Sherrill v. Oneida Indian Nation, 544 U.S. 197, 216-17 (2005); see, e.g., Oneida Indian Nation v. New York, 500 F. Supp. 2d 128, 134-37, 146-47 (N.D.N.Y. 2007) (partially dismissed under FED. R. CIV. P. 56, Summary Judgment); Seneca-Cayuga Tribe v. Town of Aurelius, 233 F.R.D. 278, 281-82 (N.D.N.Y. 2006) (dismissed under FED. R. CIV. P. 12(c), Motion for Judgment on the Pleadings); Shinnecock Indian Nation v. New York, No. 05-CV-2887 (TCP), 2006 WL 3501099, at *6 (E.D.N.Y. Nov. 28, 2006) (dismissed under FED. R. CIV. P. 12(b)(6), Failure to State a Claim). But see Paiute-Shoshone Indians, 2007 WL 521403, at *11 ("Here, however, because the issue of laches raises significant questions of fact that cannot be resolved on a motion to dismiss, it is most efficient to deny they [sic] City's motion to dismiss on the ground of laches, without prejudice to its renewal.").

15 City of Sherrill, 544 U.S. at 202 ("In the instant action, OIN resists the payment of property taxes to Sherrill on the ground that OIN's acquisition of fee title to discrete parcels of historic reservation land revived the Oneidas' ancient sovereignty piecemeal over each parcel. . . Our 1985 decision recognized that the Oneidas could maintain a federal common-law claim for damages for ancient wrongdoing in which both national and state governments were complicit." (emphasis added)).

16 See discussion infra Part III.C.

17 City of Sherrill, 544 U.S. at 217-21.

18 Cayuga Indian Nation v. Pataki, 413 F.3d 266, 277 (2d Cir. 2005) ("Inasmuch as the instant claim, a possessory land claim, is subject to the doctrine of laches, we conclude that the present case must be dismissed because the same considerations that doomed the Oneidas' claim in City of Sherrill apply with equal force here. ... We thus hold that the doctrine of laches bars the possessory land claim presented by the Cayugas here." (footnote omitted)); Oneida Indian Nation, 500 F. Supp. 2d at 133 (" $[T]$ he Court now holds that Defendants can assert a laches defense against Plaintiffs' possessory land claims."); Shinnecock, 2006 WL 3501099 , at *6 ("[W]e find that plaintiffs' possessory land claim is subject to laches, and dismiss on that basis."); New York v. Shinnecock Indian Nation, 400 F. Supp. 2d 486, 496 (E.D.N.Y. 2005) ("There are ... differences in the City of Sherrill case and the case at bar, not the least of which may be the question of the extent of the impact of the 'disruptive' claims, the nature of the Indians' present titles and possibly the length of delay and the question of laches, and appropriate remedies." (footnote omitted)).

19 See discussion infra Parts III.B-C.

20 See discussion infra Part III.C.1. 
essary to justify the invocation of the new laches defense. While elements of impossibility and acquiescence form part of this new defense, the easiest way to demonstrate the difference of this defense is to compare it to traditional laches. ${ }^{21}$ Only by tracing the original defenses can one see the major shifts from standard laches to new laches. New laches barely resembles the traditional defense of laches that has been used with relative consistency since the fourteenth century. ${ }^{22}$

The first Part of this Article reviews the Supreme Court's application of laches and equity to the Oneida Indian Nation's claim to immunity from state and local taxation, as well as the aftermath of that decision in the Second Circuit. The second Part traces the history of laches, from its first use in England through its adoption by the United States. The third Part discusses the differences between traditional laches and new laches and analyzes the significant pragmatic problems the Supreme Court and the Second Circuit have created in applying the new laches defense to Indian tribes and the United States.

\section{CITY OF SHERRILL AND BEYOND}

In City of Sherrill v. Oneida Indian Nation, the United States Supreme Court introduced the equitable defenses of laches, acquiescence, and impossibility into an area where courts had almost always barred them from being used as defenses. ${ }^{23}$ Based on lower court interpretations of City of Sherrill, ${ }^{24}$ it might also appear to a casual reader that City of Sherrill was a land claims case, when, in fact, the claim involved a tax dispute..$^{25}$ The city attempted to tax land within the historic boundaries of the Oneida reservation purchased by the Oneida Nation ("the Nation") through open-market transactions. ${ }^{26}$ The Nation sought immunity from the taxes, seeking to exercise its own sovereignty over its own lands. ${ }^{27}$ The Supreme Court chose not to follow its long line of cases focusing on tribal tax immunities, which are

21 City of Sherrill, 544 U.S. at 217-21; see also infra Part II.

22 See infra Part III.C.

23 Bd. of Comm'rs v. United States, 308 U.S. 343, 351 (1939) (citing United States v. Minnesota, 270 U.S. $181(1926))$.

24 E.g., Cayuga Indian Nation v. Pataki, 413 F.3d 266, 275 (2d Cir. 2005) ("Under the City of Sherrill formulation, this type of possessory land claim-seeking possession of a large swath of central New York State and the ejectment of tens of thousands of landowners-is indisputably disruptive.").

25 City of Sherrill, 544 U.S. at 202 ("In the instant action, ONN resists the payment of property taxes to Sherrill on the ground that OIN's acquisition of fee title to discrete parcels of historic reservation land revived the Oneidas' ancient sovereignty piecemeal over each parcel.").

26 Id. at 211-12.

27 Id. 
abundant. ${ }^{28}$ Rather, the Court focused on the disruptive nature that the exercise of the Nation's sovereignty would have on the "governance of New York's counties and towns." 29 The Court applied three defenses to the Nation's claims: laches, acquiescence, and impossibility. ${ }^{30}$ The serious doctrinal problems with this case have been well documented by others, ${ }^{31}$ and a recent case demonstrates these important commentaries have not gone unnoticed. ${ }^{32}$

The case with the potential to be the most harmful to tribal interests was decided later that same year. In 2005, the Second Circuit in Cayuga Indian Nation v. Pataki ${ }^{33}$ took City of Sherrill out of the area of taxation and into the area of general Indian land claims. ${ }^{34}$ The Second Circuit "conclude[d] that the possessory land claim alleged [in Cayuga Indian Nation] is the type of claim to which a laches defense can be applied," and "based" that conclusion on City of Sherrill. ${ }^{35}$ The case began a trend in the circuit to combine all three defenses separately identified in City of Sherrill into one defense called "laches," sometimes expressed as "disruption." ${ }^{36}$ The Cayuga Nation was initially seeking possession of the land purchased by the state in violation of the Non-Intercourse Act, a purchase never ratified by the federal government. ${ }^{37}$ In addition, the Cayuga Nation sought monetary compensation in the form of trespass damages and proceeds connected with natural resources. ${ }^{38}$ However, after nineteen years, the district court determined that ejectment would not be a proper remedy and that "monetary damages will produce results which are as satisfactory to the Cayugas as those which they could properly derive from ejectment." ${ }^{39}$ After a long pro-

28 E.g., Okla. Tax Comm'n v. Chickasaw Nation, 515 U.S. 450 (1995); Okla. Tax Comm'n v. Sac \& Fox Nation, 508 U.S. 114 (1993); Okla. Tax Comm'n v. Citizen Band Potawatomi Indian Tribe of Okla., 498 U.S. 505 (1991); Cotton Petro. Corp. v. New Mexico, 490 U.S. 163 (1989); Merrion v. Jicarilla Apache Tribe, 455 U.S. 130 (1982); White Mountain Apache Tribe v. Bracker, 448 U.S. 136 (1980); Washington v. Confederated Tribes of Colville Indian Reservation, 447 U.S. 134 (1980).

29 City of Sherrill, 544 U.S. at 202.

30 Id. at $217-21$.

31 See, e.g., Singer, supra note 4, at 608-12; Sarah Krakoff, City of Sherrill v. Oneida Indian Nation of New York: A Regretful Postscript to the Taxation Chapter in Cohen's Handbook of Federal Indian Law, 41 TULSA L. REV. 5, 7-11 (2005).

32 Oneida Indian Nation v. New York, 500 F. Supp. 2d 128, 137 n.3 (N.D.N.Y. 2007) (citing Singer, supra note 4).

33413 F.3d 266 (2d Cir. 2005).

34 This was easy to do given City of Sherrill's focus on the Oneida Indian Nation's land claims. City of Sherrill, 544 U.S. at 203-17.

35 Cayuga, 413 F.3d at 268.

36 See infra note 52.

37 Cayuga, 413 F.3d at 269.

38 Id.

39 Id. at 271 (citing Cayuga Indian Nation v. Cuomo, No. 80-CV-930, 1999 U.S. Dist. LEXIS 10579, at *79, *97 (N.D.N.Y. July 1, 1999)) 
cedural history, the district court awarded the Nation $\$ 247,911,999.42$, and both parties appealed to the Second Circuit. ${ }^{40}$

The Second Circuit held that the monetary damages were based on a claim that "is and has always been sounding in ejectment," and that ejectment is "indisputably disruptive." 41 Because of this disruption, the Nation would be subject to the "equitable considerations" described in City of Sherrill, ${ }^{42}$ even though ejectment is a legal, not equitable, claim. ${ }^{43}$ This case is where the defenses of laches, acquiescence, and impossibility start to merge into a new legal argument-the new laches defense. The Second Circuit does this by giving short shrift to the defenses of acquiescence and impossibility and by creating new prongs for laches, rather than following the traditional definition. ${ }^{44}$ Traditional laches has two prongs, delay and injury. ${ }^{45}$ The court focuses on the potential disruption of the tribal claim instead of injury to the parties. ${ }^{46}$ In fact, the Second Circuit has taken the Supreme Court's "impossibility" doctrine, normally a contract defense, and labeled it "laches." 47 The "impossibility" defense-its history is described infra at Part III-stands for the proposition that any exercise of tribal sovereignty over newly reacquired tribal land is "impossible" because of the "disruption" it would cause. ${ }^{48}$ Given that the level of "disruption" in City of

40 Id. at 273.

41 Id. at $274-75$.

42 Id. at 275.

43 DAN B. DOBBS, LAW OF REMEDIES: DAMAGES, EQUITY, RESTITUTION $\S \S 1.2$ n.2, $5.10(1)$ (abr. 2d ed. 1993).

44 Cayuga, 413 F.3d at 273-77.

45 DoBBS, supra note $43, \S 2.4(4)$, at 75 ("In its most orthodox form, laches is unreasonable delay by the plaintiff in prosecuting a claim . . . and under circumstances causing prejudice to the defendant."); see, e.g., Ottawa Tribe of Okla. v. Speck, 447 F. Supp. 2d 835, 844 (N.D. Ohio 2006) ("Laches is an equitable remedy that applies when a plaintiff has 1) unreasonably delayed in asserting his or her rights, and 2) causes prejudice to the defendant as a result of this delay." (citing Coalition for Gov't Procurement v. Fed. Prison Indus., 365 F.3d 435, 437 (6th Cir. 2004))).

46 Cayuga, 413 F.3d at 275, 277.

47 Id. at 275 ("[T]his type of possessory land claim . . . is indisputably disruptive. Indeed, this disruptiveness is inherent in the claim itself . . . rather than an element of any particular remedy ... . Accordingly, we conclude that possessory land claims of this type are subject to the equitable considerations of Sherrill."). See Kathryn E. Fort, The (In)Equities of Federal Indian Law, FED. LAW., Mar.-Apr. 2007, at 32,37-38, for a discussion of the "impossibility doctrine" that was created by the Supreme Court in City of Sherrill and appears to appeal directly to a judge's need to have a solution the judge does not consider "impossible." Therefore, anything a judge considers "disruptive" is an "impossible" solution. Rather than continuing to make these distinctions, the Cayuga court and others put this all together into a discussion of laches. See Cayuga, 413 F.3d at 273-77.

48 City of Sherrill v. Oneida Indian Nation, 544 U.S. 197, 219 (2005).

Finally, this Court has recognized the impracticability of returning to Indian control land that generations earlier passed into numerous private hands. . . In this case, the Court of Appeals concluded that the "impossibility" doctrine had no application because [the Oneida Indian Nation] acquired the land in the open market and does not seek to uproot current property owners. But the unilateral reestablishment of present and future Indian sovereign control, 
Sherrill was set at such a low bar, the Nation's exercise of sovereignty over land it already owned, ${ }^{49}$ the impossibility defense could be used to block any tribal claim. The new laches is the "impossibility" doctrine restated, and the "impossibility" doctrine has the potential to block all tribal claims.

Stating that federal Indian law is "unusually complex and confusing," the Second Circuit held that the "doctrines and categorizations applicable in other areas do not translate neatly" to Indian land claims. ${ }^{50}$ Ironically, the court cites cases that uphold provisions protecting Indian lands due to the tribe's status as a sovereign. ${ }^{51}$ Unfortunately, the complexity and confusion surrounding the Indian land claims only increased with the court's ruling in this case.

After Cayuga, courts used City of Sherrill and Cayuga to dismiss various claims at the pleadings stage, all using a combination of delay and disruption, sometimes characterized as laches or a combination of disruption and impossibility, to deny tribal claims. ${ }^{52}$ What is common, regardless of terminology, is the so-termed "disruptive" nature of the tribal claims. ${ }^{53} \mathrm{De}$ lay in bringing the claim seems primarily to be a problem as an element of disruption. ${ }^{54}$ In addition, while these are all claims based in New York, the use of laches by cities and states to defend against any kind of tribal claim has not gone unnoticed. For instance, in Paiute-Shoshone Indians v. City of Los Angeles, ${ }^{55}$ the Eastern District of California discussed equitable defenses at length with regard to a land claim only sixty-five years old that also implicated water rights. ${ }^{56}$ While the tribe avoided summary judgment, the court's discussion of the defenses is not necessarily a win for tribes be-

even over land purchased at the market price, would have disruptive practical consequences ...."

Id. (emphasis added) (citations omitted).

49 Id. at 202.

50 Cayuga, 413 F.3d at 276

51 See, e.g., Mohegan Tribe v. Connecticut, 638 F.2d 612, 614-15 (2d Cir. 1980) (recognizing that courts have rejected adverse possession defenses against Indian land claims).

52 See Shinnecock Indian Nation v. New York, No. 05-CV-2887, 2006 WL 3501099, at *3-6 (E.D.N.Y. Nov. 28, 2006) (claims dismissed based on laches); Seneca-Cayuga Tribe v. Town of Aurelius, 233 F.R.D. 278, 281-82 (N.D.N.Y. 2006) (judgment on the pleadings granted based on impossibility); Cayuga Indian Nation v. Vill. of Union Springs, 390 F. Supp. 2d 203, 206 (2005) (summary judgment granted in light of the City of Sherrill decision based on "disruption").

53 See, e.g., Shinnecock Indian Nation, $2006 \mathrm{WL} 3501099$, at *5 ("[T] he test for disruptiveness is not based on strict numeric calculations . . . The Court finds disnuptive Shinnecocks' claim that seeks the immediate ejectment of a number of defendants . . . "); Union Springs, 390 F. Supp. 2d at 206 (noting the "disruptive effects of immunity from state and local zoning laws").

54 E.g., Shinnecock Indian Nation, 2006 WL 3501099, at *5 (accepting a laches defense despite the Nation's claim that "it has not slept on its rights" because it "objected to the 1859 taking in the very year it occurred" and finding the passage of 140 years and significant changes in the property critical in holding that ejectment would have "disruptive consequences of the type that led the Supreme Court to initiate the impossibility doctrine").

55 No. 1-06-CV-00736, 2007 WL 521403 (E.D. Cal. Feb. 15, 2007).

56 Id. at $* 8-11$. 
cause the court, while recognizing that ejectment is "technically" a legal claim, agreed with Cayuga and allowed equitable defenses to be raised. ${ }^{57}$ Also disappointing is the court's reliance on Felix v.. Patrick, ${ }^{58}$ a case known for its racist undertones. ${ }^{59}$

In Ottawa Tribe v. Speck, ${ }^{60}$ the Northern District of Ohio also discussed the current state of laches under City of Sherrill and Cayuga ${ }^{61}$ The court did not dismiss on laches, but left the door open for the parties to continue to use the defense. ${ }^{62}$ In the district court's final decision, the court found that the tribe's "delay in asserting its treaty rights governing hunting and fishing in Ohio was unreasonable, and [the tribe's] justifications for the delay are not well-taken." ${ }^{13}$ Based on laches, the court found against the tribe on their claims to treaty hunting and inland fishing rights. ${ }^{64}$

These cases demonstrate a willingness by the courts to expand laches in an attempt to dismiss tribal land claims. This body of law has now created the defense of new laches, which is not based on the original definition of laches. By tracing the defense from its earliest origins, tribes and courts can see the fundamental changes in the law since City of Sherrill.

\section{TRADITIONAL LACHES FROM THE ENGLISH COURT OF EQUITY}

A lengthy historical study of laches has not been done for almost two decades. ${ }^{65}$ Given the current blend of law and equity, laches is perceived as an anachronism, especially with the prevalence of statutes of limitations. ${ }^{66}$ However, only by comparing the laches used in Indian land cases with the traditional understanding of laches can the practitioner see the stark differ-

57 Id. at $* 9-11$.

58145 U.S. 317 (1892). For a discussion of why this reference is particularly troubling, see, for example, Wenona T. Singel \& Matthew L.M. Fletcher, Power, Authority, and Tribal Property, 41 TULSA L. REV. 21, 45-47 (2005).

59 See Singel \& Fletcher, supra note 58 , at 39-41.

60447 F. Supp. 2d 835 (N.D. Ohio 2006).

61 Id. at 844-45.

62 Id. ("A court may look at the disruptive effect a plaintiff's relief would have on other parties. ... [T] he state of the current record is inconclusive and the Court cannot dismiss at this juncture." (citation omitted)).

63 Ottawa Tribe v. Ohio Dep't of Natural Res., 541 F. Supp. 2d 971, 977 (N.D. Ohio 2008).

64 Id. at 986 . The court, however, did not dismiss the tribe's claims to fishing in Lake Erie, holding there was a "dispute of material facts surrounding the prejudice to [the state] of asserting treaty rights to fish in Lake Erie ...." Id. This "prejudice" is defined as "disruption" by the court, one of the prongs of new laches. Id. at 978 .

65 See generally Gail L. Heriot, A Study in the Choice of Form: Statutes of Limitation and the Doctrine of Laches, 1992 BYU L. REV. 917.

66 Developments in the Law: Statutes of Limitations, 63 HARV. L. REV. 1177, 1179 (1950) ("In the United States today, for the great majority of actions the time for bringing suit is governed by general statutes of limitations found in every state."). 
ences between the two.$^{67}$ In Costello v. United States ${ }^{68}$ the Supreme Court defined laches as a defense that "requires proof of (1) lack of diligence by the party against whom the defense is asserted, and (2) prejudice to the party asserting the defense." ${ }^{169}$ This definition has been frequently cited. ${ }^{70}$ However, there is no mention of it in City of Sherrill and, instead, the City of Sherrill Court cited far older cases. ${ }^{11}$ By citing such old cases, the Court reinforced the age of the Oneida Nation's claim and its perceived obscurity. The cases the Court cited lead back to even older cases, to cases from England and to a specific definition of laches. ${ }^{72}$ After these citations, however, the Court went on to apply a new defense, one based on laches, but at the same time not laches. ${ }^{73}$

Generally speaking, laches is a defense in equity that stands for the proposition that a court will not find for the plaintiff if the plaintiff delayed in bringing the case, and that delay harmed the defendant. ${ }^{74}$ According to Professor George Pepper, laches only applies "if during the delay of the plaintiff there has been a loss of evidence, or by reason of the delay of the plaintiff the defendant or third persons have altered their position for the worse." 75 Accordingly, laches has traditionally had two, or at most three, components-delay, a position change for the worse, and a loss of evidence. $^{76}$

Laches originally developed in English courts of equity. These courts of equity began as chancery courts. ${ }^{77}$ The chancellor, the highest counselor and a direct representative of the king or queen, heard cases outside of the

67 The Supreme Court cited to particularly old cases in City of Sherrill. City of Sherrill v. Oneida Indian Nation, 544 U.S. 197, 217 (2005) ("It is well established that laches, a doctrine focused on one side's inaction and the other's legitimate reliance, may bar long-dormant claims for equitable relief." (citing Badger v. Badger, 69 U.S. (2 Wall.) 87, 94 (1865); Wagner v. Baird, 48 U.S. (7 How.) 234, 258 (1849); Bowman v. Wathen, 42 U.S. (1 How.) 189, 194 (1843))).

68365 U.S. 265 (1961).

69 Id. at 282 (citing Gardner v. Panama R.R. Co., 342 U.S. 29, 31 (1951); S. Pac. Co. v. Bogert, 250 U.S. 483, 488-90 (1919); Galliher v. Cadwell, 145 U.S. 368, 372 (1892)). Costello was cited by the Supreme Court as recently as 2002 in National Railroad Passenger Corp. v. Morgan, 536 U.S. 101, 121-22 (2002).

70 See, e.g., Nat'l R.R. Passenger Corp., 536 U.S. at 121-22; New Jersey v. New York, 523 U.S. 767, 806 (1998); Kansas v. Colorado, 514 U.S. 673, 687 (1995).

71 See supra note 67.

72 See supra note 67

73 City of Sherrill v. Oneida Indian Nation, 544 U.S. 197, $217-21$ (2005); see also infra Part III.B.

74 BLACK'S LAW DiCTIONARY 891 (8th ed. 2004).

75 Pepper, supra note 2, at 321.

76 See Fort, supra note 47, at 34 (arguing that loss of evidence in Indian land cases is rarely a problem because the federal government has meticulous records of treaties, land transactions, and other evidence which can be, and have been, used in Indian land claims).

77 See Heriot, supra note 65, at 926-27 (noting that courts in numerous cases from the era of Henry VIII and James I subscribed in one form or another to the substance of the doctrine of laches). 
jurisdiction of the court of common law. ${ }^{78}$ Because of the strictness of the courts of common law regarding the forms of lawsuits, parties seeking justice outside of these forms appealed directly to the king via the chancellor, who had broad jurisdiction. ${ }^{79}$ These courts were separate until the 1870 s, when England reorganized its courts and gave each the power to hear cases in both law and equity ${ }^{80}$ Prior to the reorganization, the courts of England were much as they had been for centuries, and the court of the chancery occupied the place where cases not available to be heard in the court of common pleas could be decided.

Based on pleading justice to the king himself, the chancellor decided all cases based on his conscience. ${ }^{81}$ Because of this, for many years there was no precedent; ${ }^{82}$ each chancellor had a different conscience, giving rise to the oft-cited quote: "[e]quity is a roguish thing. For law we have a measure ... equity is according to the conscience of him that is [c] hancellor, and as that is larger or narrower, so is equity." 83 Records indicate that the chancellor began hearing disputes on behalf of the king during the reign of Richard II, from 1377 to $1399 .{ }^{84}$ The rise of the equitable courts of the chancery corresponds directly with a time of violence and unrest when no fewer than four kings were murdered by their successors, from 1399 to $1485 .{ }^{85}$ As one commentator noted:

78 JOHN MCGHEE, SNELL's PRINCIPLES OF EQUITY 6-7 (30th ed., Sweet \& Maxwell Ltd. 2000) (1868).

79 Id.; 3 SAMUEL R. GARDINER, History OF ENGLAND FROM THE ACCESSION OF JAMES I TO THE OUTBREAK OF THE CIVIL WAR 1603-1642, at 10 (1965) ("A custom had gradually arisen of seeking redress in Chancery, in cases where the Common Law courts had failed to do justice on account of the strictness of the rules which they had laid down for their guidance.").

80 Philip S. JAmes, InTROduction To ENGLish LAw 41 (10th ed. 1979) ("By these Acts the superior courts were reorganized and were placed substantially upon their present-day footing.").

81 MCGHEE, supra note 78, at 7 ("In the Middle Ages the Chancellor's jurisdiction was undefined. His powers were wide but vague, and coextensive only with the necessity that evoked them. He exercised his powers on the ground of conscience.").

82 Fiona R. Burns, The Court of Chancery in the 19th Century: A Paradox of Decline and Expansion, 21 U. QUEENSLAND L.J. 198, 201 (2001).

83 Thomas O. Main, Traditional Equity and Contemporary Procedure, 78 WASH. L. REV. 429, 445 (2003).

84 Willard Barbour, Some Aspects of Fifteenth-Century Chancery, 31 HARV. L. REV. 834, 840 (1918); see also 3 JOHN REEVES, HISTORY OF THE ENGLISH LAW FROM THE TIME OF THE SAXONS to THE END OF THE REIGN OF PHILIP AND MARY 194 (2d ed. 1787) (citing a statute by Richard II establishing the jurisdiction of the chancery, which "may be considered as a legislative sanction to its establishment ...').

85 Richard II was deposed in 1399 by Henry IV, Henry VI was deposed by Edward IV in 1461, Edward V was deposed by Richard III in 1483, and Richard III was deposed by Henry VII in 1485. Christine Carpenter, THE Wars of the Roses: Politics and the Constitution IN ENGland, $c$. 1437-1509, at 9, 116, 209, 217 (1997); Barbour, supra note 84, at 849 (noting the rise of petitions to the Chancellor as "very common" by the time of Henry V). 
It is in brief the complete breakdown of the system of criminal justice which occasioned the Chancellor's action. Beyond question appears the imperative need in mediæval England for a great judge who had the prestige and power to suppress the outrages of offenders who were strong enough to put at naught the ordinary processes of the law... . Certainly the petitions [in equity] bear witness to the belief among all classes that in the Chancellor resided a general power to redress all wrongs if for any reason the person injured could not protect himself through the common law. ${ }^{86}$

Why a period of regal weakness led to the rise of the chancellor's jurisdiction is not immediately apparent. Few commentators or current writers mention this parallel. ${ }^{87}$ Perhaps the rule of law expressed through the common law courts had no efficacy to the citizens suffering from the wars between the king and his nobles. For whatever reason, however, by the end of the period of disruption, the power of the chancellor to decide cases was firmly established. ${ }^{88}$ Cardinal Wolsey, who exercised tremendous power under Henry VIII, used his chancery decisions to further the reach of equity jurisprudence, creating four equity courts to hear additional petitions ${ }^{89}$ Interestingly, this expansion was later used by Parliament against him during his removal..$^{90}$ During the reign of James I, a dispute broke out between the proponents of law and equity. ${ }^{91}$ The king, understanding equity to be his power, sided with those promoting equity, ${ }^{92}$ and the courts of both have continued to this day in some jurisdictions, though they now have merged in both England and the United States federal system. ${ }^{93}$

Eventually, even though chancery began with equity jurisdiction that changed with the chancellor, maxims developed, particularly as the chancellor began farming out his work to lower courts. ${ }^{94}$ The maxims provided

86 Barbour, supra note 84 , at 857.

87 See J.A. Guy, The Development of Equitable Jurisdictions, 1450-1550, in LAW, LITIGANTS AND THE LEGAL Profession 80, 81 (E.W. Ives \& A.H. Manchester eds., 1983) (discussing M.E. Avery's contention that the rise of the chancellor was for protection of private rights during the Wars of the Roses).

88 See id.

89 See EdWard Foss, BIographia JuRIdica: A BIographiCal Dictionary OF THE Judges of ENGLAND FROM THE CONQUEST TO THE PRESENT TIME, 1066-1870, at 752-54 (1870).

90 See id. at 756 (" [A]lthough [Wolsey] had a complete defense . . . in the royal license confirming the authority under which he acted, he at once saw, in this revival of an obsolete statute . . . a preconcerted determination to effect his ruin.").

91 See GARDINER, supra note 79, at 1-6; Main, supra note 83, at 446 (discussing the relatively famous dispute in London between Lord Coke and Lord Bacon).

92 Main, supra note 83 , at $446 \&$ n. 109.

93 See id. at 474-76. But see generally Donald J. Wolfe, Jr. \& Michael A. Pittenger, CoRPORATE AND COMmercial Practice IN THE DELAWARE COURT OF CHANCERY § 2.02[a] (2008) (discussing Delaware as one example of a jurisdiction that has chosen to keep a separate court of chancery for historical and practical considerations).

94 See 4 REEVES, supra note 84 , at 380; MCGHEE, supra note 78, at 8 ("What had begun as an irregular process of petitioning the Crown in extraordinary circumstances had become a regular system of courts with a recognised jurisdiction."). 
guidance for the judges and developed both the claims and defenses in equity. ${ }^{95}$ One of the defenses was laches, which was one way the court of chancery determined the fairness of a claim. ${ }^{96}$ Long delays in bringing a claim created a number of harms, including the loss of evidence, the position of the defendant, and the perception of unstable law. ${ }^{97}$

The word laches itself stems from the French word, la lachesse, for negligence or delay. ${ }^{98}$ Even before the rise of the courts of chancery, delay in bringing a claim was something the courts looked to avoid. The doctrine was used as early as 1311 in a property inheritance dispute. ${ }^{99}$ A woman brought a claim through her second husband regarding a land issue. ${ }^{100}$ The claim itself was old and, in its decision, the court discussed the issue of laches. ${ }^{101}$ The plaintiff had to wait until the death of her first husband to bring the claim. ${ }^{102}$ Though written in 1311, the court's discussion of laches is recognizable to modern legal scholars because its definition has changed only slightly since then; the party bringing the claim is accused of a delay that harmed the defendant. ${ }^{103}$ The court appeared ready to apply laches if the petitioner had been a man; however, because the petitioner was a woman, the court decided laches was not an appropriate remedy. ${ }^{104}$ The fact that the petitioner was a woman made the application of laches unfair because she had to wait until her husband's death to bring the claim. ${ }^{105}$ The court was not a court of equity, but still viewed laches as malleable, requiring a balancing of fairness on both sides. ${ }^{106}$ This doctrine also gave the

95 See John M. GoOdenow, Historical SKetChes of THE PRINCIPLES AND MAXIMS of AMERICAN JURISPRUDENCE, IN CONTRAST WITH THE DOCTRINES OF ENGLISH COMMON LAW ON THE SUBJECT OF CRIMES AND PUNISHMENTS 83 (photo. reprint 1972) (1819).

96 See Heriot, supra note 65, at 926-27 ("Power was vested in the equity judge to do what was best.").

97 See Mackall v. Casilear, 137 U.S. 556, 566 (1890) ("The doctrine of laches is based upon grounds of public policy, which requires for the peace of society the discouragement of stale demands; and where the difficulty of doing entire justice by reason of the death of the principal witness or witnesses, or from the original transactions having become obscured by time, is attributable to gross negligence or deliberate delay ...."); see also Smith v. Clay, (1767) 3 Bro. C.C. 646, 29 Eng. Rep. 743, 745 (Ch.) ("And the public peace requiring an end of suits.").

98 Antoni Vaquer, Verwirkung Versus Laches: A Tale of Two Legal Transplants, 21 TUL. EUR. \& Crv. L.F. 53, $54-55$ n. 4 (2006).

99 See id. at 55 (citing Gascelyn v. Rivere, Y.B. 4 Edw. 2 (1311), reprinted in 42 SELDEN SOCIETY $50,54(1926))$.

100 Gascelyn, 42 SELDEN SOCIETY at 50.

101 See id. at 54.

$102 I d$.

103 See id. at 53.

104 See id. at 54.

105 See id.

106 Gascelyn, 42 SELDEN SOCIETY at 53-54. 
court flexibility, as there was no set time for how long of a delay invoked laches. ${ }^{107}$

This flexibility in the doctrine was cited more than five hundred years later by another English court. In Lindsay Petroleum v. Hurd, ${ }^{108}$ Sir Barnes Peacock held that "the doctrine of laches in Courts of equity is not an arbitrary or a technical doctrine." 109 An even earlier English case held that "[m]ere lapse of time does not bar in equity any more than at law: it is an ingredient which, with other circumstances, may lead the [c]ourt to draw inferences unfavourable to the claim of a party who has let twenty or nearly twenty years elapse without asserting his right." 110

As with other equitable defenses, certain maxims developed around the use of laches. There was tension in the old English equity courts over what John Kroger differentiates as traditional equity and modern equity. ${ }^{11 \prime}$ Traditional equity was enforcing "natural law," having no set rules or precedent. ${ }^{112}$ Modern equity, as defined by Blackstone, had rules and precedent and was similar to the common law. ${ }^{113}$ In regards to laches, those rules included the definition of laches (delay and injury), the establishment of laches as an equitable defense (rather than a legal one), the fact that laches required a balancing of the particular equities of each case, the fact that laches generally did not bar a suit if brought within the period set by the applicable statute of limitations, the requirement that the defendant have clean hands when arguing laches, and the fact that laches could not be applied to the sovereign. ${ }^{114}$

\section{EQUITY IN THE UNITED STATES}

Equity jurisprudence survived in the United States after the Revolutionary War and was based entirely on English equity jurisprudence. ${ }^{115}$ While it is true that "there was no confusing the Supreme Court with a Chancellor who wielded the Crown's delegated prerogative to 'do justice' according to conscience and despite the law," 116 by 1787 each of the thir-

107 See id. at 54.

108 (1874) 5 L.R.-P.C. 221 (appeal taken from Ont.).

109 Id. at 239.

110 Penny v. Allen, (1857) 7 De G.M. \& M. 409, 426, 44 Eng. Rep. 160, 166 (Ch.).

111 John R. Kroger, Supreme Court Equity, 1789-1835, and the History of American Judging, 34 Hous. L. REV. 1425, 1433-37 (1998).

112 Id. at $1433-35$.

113 Id. at 1438.

114 See 2 JoHn NORTON POMEROY, A TREATISE ON EQUITY JURISPRUDENCE AS ADMINISTERED IN THE UNITED STATES OF AMERICA § 419 (Spencer W. Symons ed., 5th ed. 1941) (1881); 21 C.J. § 216 (1920).

115 Main, supra note 83 , at $449-50$

116 Laura S. Fitzgerald, Is Jurisdiction Jurisdictional?, 95 Nw. U. L. REV. 1207, 1256 (2001). 
teen colonies had given their courts the power to hear cases in equity. ${ }^{117}$ Article III, section 2 of the United States Constitution gave the newly established federal court jurisdiction to hear "all cases, in law and equity." 18 Justice Story, as a circuit justice in 1821, found that the equity jurisdiction of the federal courts "does not depend on what is exercised by courts of equity, or courts of law, in the several states; but depends upon what is a proper subject of equitable relief in the courts of equity in England, the great reservoir from which we have extracted our principles of jurisprudence." $" 19$ In addition, Justice Story asserted that, in passing the 1877 judiciary statute, "there could be no doubt that the legislature intended to confer upon the court jurisdiction as developed in equity in England at that time." 120 Indeed, early jurists believed the "and" in the clause of the law and equity portion of the Constitution required separate rules and separate causes of action. ${ }^{121}$ In addition, the Federal Rules of Equity, first adopted by the Court in 1822, stated whenever existing rules in the United States did not apply to a case in equity, "the practice of the Circuit Courts shall be regulated by the practice of the High Court of Chancery in England." 122 This rule was modified twenty years later to state that the practice of the High Court of Chancery in England may be used "not as positive rules, but as furnishing just analogies to regulate the practice."123

While the United States did not have a separate court system to hear cases in equity, the Federal Rules of Equity governed all federal equity cases until 1938, when they were merged with the Federal Rules of Civil Procedure. ${ }^{124}$ However, the Supreme Court in 1893 stressed equity's service to the law, holding in Hedges v. Dixon County: ${ }^{125}$

Courts of equity can no more disregard statutory and constitutional requirements and provisions than can courts of law. They are bound by positive provisions of a statute equally with courts of law, and where the transaction, or the contract, is declared void because not in compliance with express statutory or constitutional provision, a court of equity cannot interpose to give validity to such transaction or contract, or any part thereof. ${ }^{126}$

117 Kroger, supra note 111, at 1438.

118 U.S. CONST. art. III, § 2.

119 Bean v. Smith, 2 F. Cas. 1143, 1150 (C.C.D.R.I. 1821).

120 JOSEPH STORY, 1 COMMENTARIES ON EQUITY JURISPRUDENCE, AS ADMINISTERED IN ENGLAND AND AMERICA 28 (W.H. Lyon, Jr. ed., 14th ed. 1918) (1835) (referring to Pub. Stats. Ch. 151 § 4); see also Main, supra note 83 , at 450 .

121 JAMES Love HoPkINS, THE NEW FEDERAL EQUTTY RULES 2 (8th ed. 1933) (1913).

122 Federal Equity Rule 38, reprinted in HOPKINS, supra note 121, at 42.

123 Federal Equity Rule 90, reprinted in HOPKINS, supra note 121, at 61.

124 Main, supra note 83, at 431.

125150 U.S. 182 (1893).

126 Id. at 192. 


\section{A. Laches and the Supreme Court}

As pointed out in a 1998 article, there are few historical discussions of Supreme Court equity jurisprudence. ${ }^{127}$ Professor Kroger argues there were two models for equity jurisdiction, one highly discretionary and the other more formal and constrained. ${ }^{128}$ This plays out in these early laches cases as a "lack of interest" in precedent. ${ }^{129}$ Professor Kroger argues that between 1789 and 1801 , the Court cited to only two cases in their seventeen equity opinions. ${ }^{130}$ However, with the advent of Marshall's Court, highly influenced by Blackstone, ${ }^{131}$ the Court began using a more modern, familiar decision style, dispensing with seriatum opinions for the most part. ${ }^{132} \mathrm{~A}$ result of this change was the Court's refusal to use laches in some cases because of its elastic tendencies. ${ }^{133}$ However, according to Professor Kroger, the Court's philosophy swung back as the Marshall Court aged, evoking a description by Kroger of the Court's equity jurisdiction as "unprincipled discretion" and a definition of which would be familiar to those reading City of Sherrill. "[T] is, in every case, discretionary. Instead, the Court claims that its reasoning is formal, outcome-neutral, and precedent-bound when that approach serves its own purpose, but invokes discretionary powers when it wishes to intervene to protect powerful or highly valued interests." 134 While the Supreme Court has developed precedent around the equitable defense of laches and decided a highly cited case on the defense as recently as $1961,{ }^{135}$ the City of Sherrill Court cited to far older cases in its discussion that themselves rely on the older English cases. The 1843 case cited in City of Sherrill was Bowman v. Wathen. ${ }^{136}$ The case concerned the competing claims of a ferry permit, one of many cases concerning the development of new cities, territories, and states as each entity purported to pass valid title to different devisees. ${ }^{137}$ The defendants considered their title to be settled for at least thirty-eight years and, while the court acknowledged the defendants likely maintained their ferry for profit, the "undertaking [was] highly promotive of public advantage." ${ }^{138}$ This is illuminating because of the Court's adop-

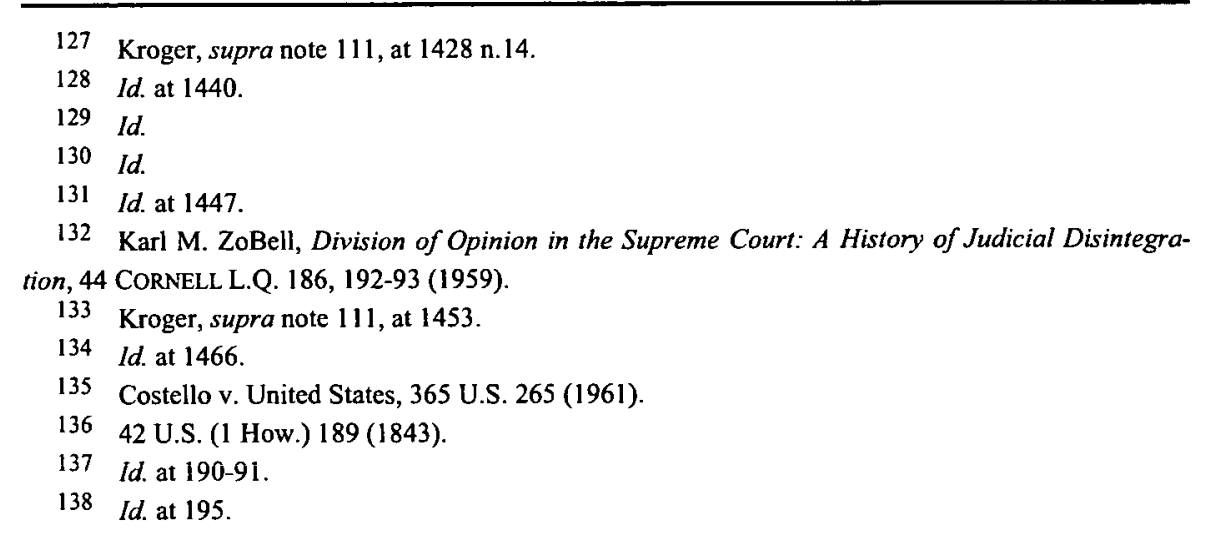


tion of weighing public rights and interests against the implementation of laches. In the Court's discussion of laches, the Court cited approvingly to Smith v. Clay, ${ }^{139}$ an English case from $1767 .{ }^{140}$ In that case, Lord Camden discussed a petition to review a decree that was between thirty and forty years old. ${ }^{141}$ While he stated that, after twenty years, most appeals would be barred:

\begin{abstract}
A court of equity which is never active in relief against conscience, or public convenience, has always refused its aid to stale demands, where the party has slept upon his right and acquiesced for a great length of time. Nothing can call forth this court into activity, but conscience, good faith, and reasonable diligence; where these are wanting, the [c]ourt is passive, and does nothing. Laches and neglect are always discountenanced, and therefore from the beginning of this jurisdiction, there was always a limitation to suits in this court. ${ }^{142}$
\end{abstract}

The Supreme Court and English courts have frequently referred to Smith $v$. Clay when defining laches. ${ }^{143}$ It is one of the first laches cases to cite to its own precedent, Edwards v. Carroll ${ }^{144}$ and Fitton v. Lord Macclesfield. ${ }^{145}$ Tracing laches through precedent stops at these cases (from 1760 and 1684, respectively). ${ }^{146}$ Lord Macclesfield held that "though there be no limitation of time to the bringing a bill of review; yet after two and twenty years he should not reverse a decree, but upon very apparent and flat errors." 147 In addition, Smith $v$. Clay stands for the proposition that "when the Legislature ha[s] fixed the time at law, it would have been preposterous for equity (which, by its own proper authority, always maintained a limitation), to countenance laches beyond the period, that law had been confined to by parliament." 148

While these historic cases generally find length of time a bar, they still illustrate a way for the plaintiff to argue against the application of laches. For example, in Wagner $v$. Baird, ${ }^{149}$ a case cited in City of Sherrill, ${ }^{150}$ the Court stated that length of time "operates by way of presumption in favor of

139 (1767) 3 Bro. C.C. 646, 29 Eng. Rep. 743, 745 (Ch.).

140 Wathen, 42 U.S. at 193 ("They have been imbodied by Lord Camden, with a succinctness, and at the same time with a comprehensiveness, compressing within a few sentences almost a system of equity jurisprudence ....").

141 Smith, 29 Eng. Rep. at 744.

142 Id. (emphasis added).

143 See, e.g., Wathen, 42 U.S. at 193.

144 (1760) 2 Bro. P.C. 98, 1 Eng. Rep. 817 (Ch.).

145 (1684) 1 Vern 287, 23 Eng. Rep. 474 (Ch.). Fitton is transcribed as "Fitter" in Smith.

146 See Main, supra note 83 , at $447-48$. Carroll was decided around the time the courts of the chancery began using precedent to decide cases. Cases after Carroll tend to cite precedent, cases before tend not to, at least regarding laches. See id.

147 Lord Macclesfield, 23 Eng. Rep. at 477.

148 Smith, 29 Eng. Rep. at 744.

14948 U.S. (7 How.) 234 (1849)

150544 U.S. 197, 217 (2005). 
the party in possession." 151 However, it also held that "[1]ong acquiescence and laches ... cannot be excused but by showing some actual hindrance or impediment caused by the fraud or concealment of the party in possession . ..."152 Badger v. Badger, ${ }^{153}$ the primary case cited by the City of Sherrill Court for the proposition that equity courts refuse old cases "for the peace of society," "154 also stated that "[t]he numerous cases in the books as to dismissing a chancery bill because of staleness, would seem to be contradictory if the dicta of the chancellors are not modified by applying them to the peculiar facts of the case under consideration."1ss

Costello v. United States, ${ }^{156}$ a Supreme Court case from 1961, is often cited for the definition of laches. ${ }^{157}$ When the Supreme Court decided Costello, it cited multiple cases to come up with its two-step definition of laches. ${ }^{158}$ Those cases included Galliher v. Cadwell, ${ }^{159}$ which argued that past cases "all proceed upon the theory that laches is not, like limitation, a mere matter of time; but principally a question of the inequity of permitting the claim to be enforced, an inequity founded upon some change in the condition or relations of the property or the parties." 160 Costello also cited Southern Pacific Co. v. Bogert, ${ }^{161}$ which stated, "[n]or does failure, long continued, to discover the appropriate remedy, though well known, establish laches where there has been due diligence, and, as the lower courts have here found, the defendant was not prejudiced by the delay." 162 Finally, the Court cited to Gardner v. Panama Railroad Co., ${ }^{163}$ which discussed laches as an elastic defense:

Though the existence of laches is a question primarily addressed to the discretion of the trial court, the matter should not be determined merely by a reference to and a mechanical application of the statute of limitations. The equities of the parties must be considered as well.

\footnotetext{
151 Baird, 48 U.S. at 258.

152 Id.

15369 U.S. (2 Wall.) 87 (1864).

154 City of Sherrill, 544 U.S. at 217.

155 Badger, 69 U.S. at 92.

156365 U.S. 265 (1961).

157 E.g., Nat'l R.R. Passenger Corp. v. Morgan, 536 U.S. 101, 122 (2002); New Jersey v. New York, 523 U.S. 767, 806 (1998); Kansas v. Colorado, 514 U.S. 673, 687 (1995).

158 Costello, 365 U.S. at 282 ("Laches requires proof of (1) lack of diligence by the party against whom the defense is asserted, and (2) prejudice to the party asserting the defense." (citing Galliher v. Cadwell, 145 U.S. 368, 372 (1892); S. Pac. Co. v. Bogert, 250 U.S. 483, 488-90 (1919); Gardner v. Panama R.R. Co., 342 U.S. 29, 31 (1951))).

159145 U.S. 368 (1892).

$160 \quad I d$ at 373.

161250 U.S. 483 (1919).

162 Id. at 490.

163342 U.S. 29 (1951).
} 
Where there has been no inexcusable delay in seeking a remedy and where no prejudice to the defendant has ensued from the mere passage of time, there should be no bar to relief. ${ }^{164}$

Most recently, Costello's laches definition was quoted by the Supreme Court in 2002. ${ }^{165}$ While the Court was not reaching a finding on laches, it was trying to illustrate some defenses an employer might use against a Title VII suit. ${ }^{166}$ However, even with all of this precedent and historical background, the Court in City of Sherrill did not use these cases and, in failing to do so, created a new defense for states and cities against Indian land and treaty claims.

\section{B. New Laches: Acquiescence and Impossibility in City of Sherrill}

New laches is the merging of acquiescence, impossibility, and the delay prong of laches. Acquiescence and impossibility were both used by the City of Sherrill Court. ${ }^{167}$ Acquiescence, like laches, is based in history and precedent, and was also an equitable defense. ${ }^{168}$ Acquiescence is at times confused with laches, but commentators insist there is a distinct difference between them. ${ }^{169}$ Acquiescence requires knowledge by the plaintiff at the time of the wrong and requires the plaintiff to actively assent to the performance. ${ }^{170}$ An English case from 1861 held: "acquiescence . . . imports knowledge, for I do not see how a man can be said to have acquiesced in what he did not know." 171 In addition, the case of De Bussche v. Alt ${ }^{172}$ held that acquiescence cannot happen after the injury has occurred because " $[\mathrm{m}]$ ere submission to the injury for any time short of the period limited by statute for the enforcement of the right of action cannot take away such right [to sue]." 173

While acquiescence has been used in other legal settings, most Supreme Court jurisprudence is in the area of state boundary disputes. Indeed,

\footnotetext{
164 Id. at 30-31.

165 Nat'l R.R. Passenger Corp. v. Morgan, 536 U.S. 101, 122 (2002).

166 Id. at 121-22.

167 City of Sherrill v. Oneida Indian Nation, 544 U.S. 197, 218-21 (2005).

168 See, e.g., Wagner v. Baird, 48 U.S. (7 How.) 234, 258 (1849) (explaining that courts of equity often refuse to interfere in cases where long acquiescence to an asserted adverse right has occurred).

169 See 4 POMEROY, supra note $114, \S 1440$, at 3410 ("The subject is further complicated by a hopeless confusion in nomenclature. The term 'acquiescence,' in one of its two legal significations, is often used interchangeably with the term 'laches' ....").

17028 AM. JUR. 2D Estoppel and Waiver $\S 63$ (2008).

171 Life Ass'n of Scotland v. Siddal, (1861) 3 De G.F. \& J. 58, 45 Eng. Rep. 800, 806 (Ch.).

172 (1878) 8 Ch.D. 286.

173 Id. at 314.
} 
these are the cases the Court cited in City of Sherrill. ${ }^{174}$ In most of these cases, years go by with one state exercising sovereignty, such as taxation and civil regulation, over a piece of land. ${ }^{175}$ Eventually, a second state challenges that exercise and argues that the piece of land should belong to the second state. ${ }^{176}$ The case must go to the Supreme Court under its limited original jurisdiction. ${ }^{177}$ In one of the earliest of these cases, Indiana and Kentucky fought over the ownership of Green River Island. ${ }^{178}$ In seeking to resolve the conflict, the Supreme Court relied on the finding that, for seventy years, Indiana "never exercised, or attempted to exercise, a single right of sovereignty or ownership over its soil." 179 Therefore, Indiana's "acquiescence in the assertion of authority by the state of Kentucky, such omission to take any steps to assert her present claim by the state of Indiana, can only be regarded as a recognition of the right of Kentucky too plain to be overcome except by the clearest and most unquestioned proof." 180 This case was cited approvingly by the Court in $1926^{181}$ and in $1973,{ }^{182}$ which are two of the acquiescence cases cited by the City of Sherrill Court. ${ }^{183}$

A traditional difference between acquiescence and laches is that the Court will generally not apply laches to land claims between states, even when the claim is old. ${ }^{184}$ This is a small distinction, but nonetheless, claims between states are not summarily barred based on the length of time since the start of the claim. ${ }^{185}$ One illustrative case demonstrates this distinction. In a dispute between Rhode Island and Massachusetts, all that was required of Rhode Island to avoid dismissal based on laches was to "aver[] that she never acquiesced in the boundary claimed by the defendant, but has continually resisted it, since she discovered the mistake; and that she has been prevented from prosecuting her claim, at an earlier day, by the circumstance mentioned in her bill." 186 Massachusetts agreed that Rhode Island "never acquiesced, and has, from time to time, made efforts to regain the territory, by negotiations with Massachusetts, and was prevented ... from appealing

174544 U.S. 197, 218 (2005) (citing Califomia v. Nevada, 477 U.S. 125 (1980); Ohio v. Kentucky, 410 U.S. 641 (1973); Michigan v. Wisconsin, 270 U.S. 295 (1926); Massachusetts v. New York, 271 U.S. 65 (1926)).

175 See, e.g., Indiana v. Kentucky, 136 U.S. 479, 509-10 (1890).

$176 I d$.

177 U.S. CONST. art. III, $\$ 2$.

178 Indiana, 136 U.S. at 503.

179 Id. at 510.

180 Id.

181 Michigan v. Wisconsin, 270 U.S. 295, 319 (1926).

182 Ohio v. Kentucky, 410 U.S. 641,651 (1973).

183 City of Sherrill v. Oneida Indian Nation, 544 U.S. 197, 218 (2005).

184 See, e.g., Rhode Island v. Massachusetts, 40 U.S. (15 Pet.) 233, 273 (1841).

$185 \mathrm{Id}$.

186 Id. at 272. 
to the proper tribunal to grant her redress." 187 This boundary claim dispute, which one lawyer claimed was about "territory [that] is densely inhabited, and under a high state of improvement; . . it is occupied by seven thousand people, all of whom, as did their ancestors to remotest time, deem themselves to be citizens, and most of them native citizens of Massachusetts; and that there is upon it not less than a million dollars of taxable property," 188 was nearly one hundred years old. ${ }^{189}$ Laches did not bar the claim because "here two political communities are concerned, who cannot act with the same promptness as individuals." 190

Both laches and acquiescence in City of Sherrill have historical underpinnings, but the City of Sherrill Court's use of "impossibility" does not comport with any historical understanding of that remedy. Impossibility, as an equitable doctrine, was only used in contract cases where it would be "impossible" for one party to perform on the contract. ${ }^{191}$ The preeminent case in this area is Taylor v. Caldwell, ${ }^{192}$ which involved the destruction of a music hall before the contracted performances could be held. ${ }^{193}$ The court held that " $[t]$ he principle seems to us to be that, in contracts in which the performance depends on the continued existence of a given person or thing, a condition is implied that the impossibility of performance arising from the perishing of the person or thing shall excuse the performance." ${ }^{194}$ While Taylor v. Caldwell is the most recognized of impossibility cases, one commentator has found English cases from as early as 1536 that allowed impossibility as an excuse for performance. ${ }^{195}$ However, impossibility as a remedy does not exist outside of contracts (and a narrow area of criminal law), except as the Supreme Court used it in City of Sherrill. ${ }^{196}$ According to City of Sherrill, the doctrine of impossibility stands for the proposition that any exercise of tribal sovereignty that might have "disruptive practical consequences" is impossible. ${ }^{197}$ This is not the understanding of impossibility in any other legal circumstance. For instance, the Court relied on Yankton Sioux v. United States. ${ }^{198}$ However, the Court's reliance on Yankton Sioux is problematic because the Court's use of it in City of Sherrill is based on dic-

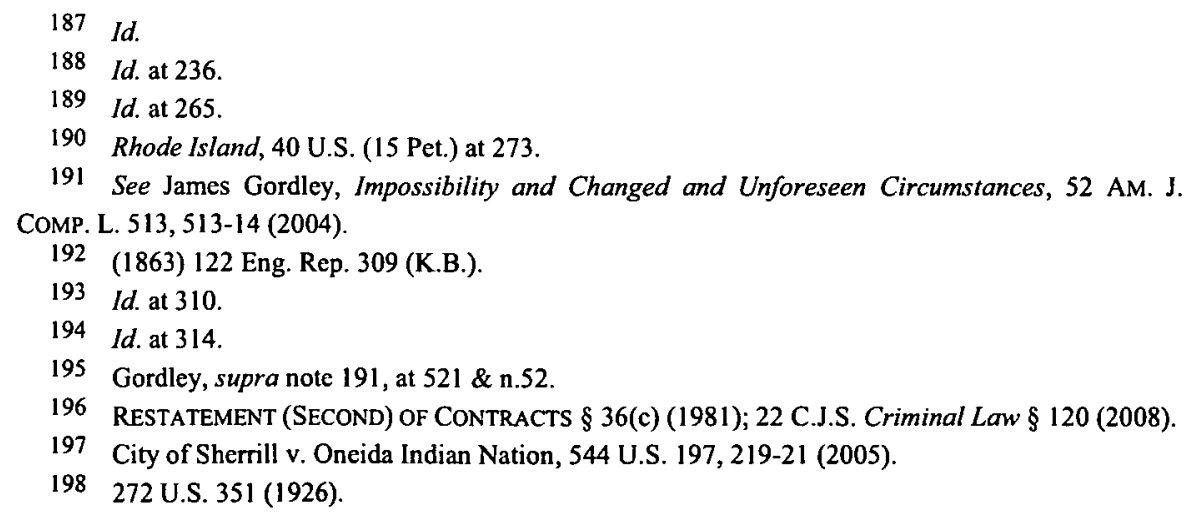


ta in Yankton Sioux. ${ }^{199}$ The Supreme Court heard the Yankton Sioux case as it was appealed through the Court of Claims. ${ }^{200}$ In a treaty from 1858, the Yankton Band of Santee Sioux reserved 400,000 acres of land known as the red pipestone quarries. ${ }^{201}$ After years of pressure on the tribe by non-Indian squatters, federal agents, and Congress to give up title and rights to the quarries, the Yankton Sioux finally had their claim heard by the Supreme Court. ${ }^{202}$ The Supreme Court was asked to determine whether the red pipestone quarries had been wrongly taken by the United States, and if so, what just compensation the tribe deserved. ${ }^{203}$ The federal government, basing its argument on an 1894 agreement with the tribe it claimed was void, argued the federal government owned the land and, therefore, did not owe just compensation. ${ }^{204}$ The Supreme Court, however, interpreted the provision otherwise. The provision of the 1894 agreement stated that if Congress questioned the ownership of the Pipestone reservation, the Secretary of the Interior was to refer the question to the Supreme Court within one year. ${ }^{205}$ If the matter was not referred within the year, the land would automatically become the tribe's in fee. ${ }^{206}$ Because referring the matter to the Supreme Court would be an illegal expansion of the Court's original jurisprudence, the federal government claimed the clause was impossible, and therefore the entire agreement void. ${ }^{207}$

Congress eventually authorized the Court of Claims to hear the case because, while the land was reserved to the tribe in an 1858 treaty, it had been forced open to settlement by the actions of the railroad, federal agents, and Congress. ${ }^{208}$ Once the claim arrived in the Supreme Court, the federal government argued the tribe did not own the land in fee because the 1894 agreement was void. ${ }^{209}$ The Court found, however, that the second portion of the clause, which passed fee to the tribe if the government did not act,

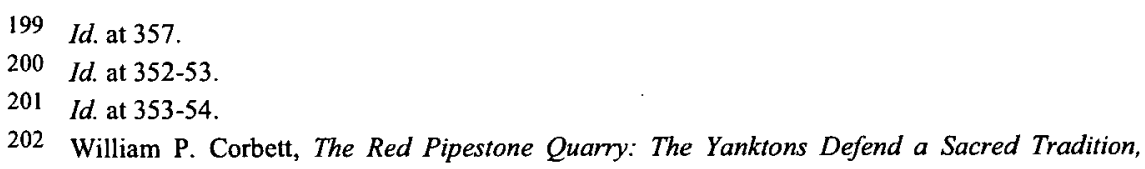
1858-1929, 8 South Dakota History 99, 101-14 (Winter 1977). Indeed, the Congressional Task Force that prepared the American Indian Religious Freedom Act Report stated "this quarry was deliberately damaged by the construction of a railroad through it in 1891 at the instigation of federal officials and missionaries who wished to destroy its value as a religious site." Department of the Interior, American Indian Religious Freedom Act Report, P.L. 95-341, at 14 (Aug. 1979).

203 Yankton Sioux, 272 U.S. at 353.

204 Id. at $354-55$

205 Id. at 355

206 Id.

207 See id. at 355-58. It is not clear from the record why the federal government did not argue the agreement was unconstitutional. According to the Court, the Secretary of the Interior "conclude[d] that the provision for referring the matter to this court was beyond the constitutional power of Congress." Id. at 355 .

208 Corbett, supra note 202, at 106-07.

209 See Yankton Sioux, 272 U.S. at 356-58. 
was an alternative option that was not impossible. ${ }^{210}$ Therefore, finding the agreement void because of the impossible term would be "most inequitable and utterly indefensible on any moral ground . ..."211 The tribe held the land in fee, but it was agreed that the federal government was in possession. The Court awarded "just compensation" to the tribe for the taking by the government. ${ }^{212}$

Yankton Sioux is now cited for the proposition that if there are two alternative manners of performing on a contract, and one is impossible, the contract is not rendered void if the alternate manner is available. ${ }^{213}$ Various federal courts have cited this case for this proposition and go so far as to state that the case is "[o]ne of the best examples of the application of this doctrine ...."214 The only time the Court in Yankton Sioux specifically discussed equity was when it addressed the federal government's attempt to claim the entire agreement void because of the impossibility of performance. $^{215}$ In dicta, the Court did state that returning land to the Indians that had already been sold to "innocent" purchasers would be "impossible."216 The ultimate holding of the case, however, was that the United States took the land, and the tribe was due just compensation for the taking. ${ }^{217}$

Yankton Sioux did not create a new impossibility defense for Indian land claims. Rather, it expressed a new wrinkle to the contracts impossibility defense. The City of Sherrill Court, however, cited the case for the stance that the "Court has recognized the impracticability of returning to Indian control land that generations earlier passed into numerous private hands." $" 218$

The City of Sherrill Court used pieces of acquiescence, impossibility, and laches to create the new laches defense. For example, the City of Sherrill Court pulled from acquiescence the notion that simple length of time can bar a claim. Specifically, the City of Sherrill Court noted that "longstanding observances and settled expectations are prime considerations" in

\footnotetext{
$210 \quad I d$. at $357-58$.

211 Id. at 357.

212 Id. at 359.

213 See, e.g., Brangier v. Rosenthal, 337 F.2d 952, $953-54$ (9th Cir. 1964); Crowley v. Commodity Exch., 141 F.2d 182, 189 (2d Cir. 1944).

214 Ashland Oil \& Ref. Co. v. Cities Serv. Gas Co., 462 F.2d 204, 211 (10th Cir. 1972).

215 Yankton Sioux, 272 U.S. at 359.

216 Id. at 357 ("It is impossible, however, to rescind the cession and restore the Indians to their former rights, because the lands have been opened to settlement and large portions of them are now in the possession of innumerable innocent purchasers, and nothing remains but to sanction a great injustice or enforce the alternative agreement of the United States in respect of the ownership of the Indians.").

217 Id. at 359.

218 City of Sherrill v. Oneida Indian Nation, 544 U.S. 197, 219 (2005). Of course, in Yankton Sioux the land had only been in "private hands" for twenty-six years, hardly "generations." Yankton Sioux, 272 U.S. at 352-55.
} 
a land claim. ${ }^{219}$ The Court even went so far as to state that "[t]he acquiescence doctrine does not depend on the original validity of a boundary line; rather, it attaches legal consequences to acquiescence in the observance of the boundary" which divides the taking of land in violation of federal law from the consequences of that taking. ${ }^{220}$ This reasoning helps eliminate any need to evaluate past inequities in the face of the current situation, focusing court opinions back on disruption of current landowners rather than a more traditional weighing of equities.

The Court's discussion of impossibility is consistent with the larger creation of the defense of new laches. Impossibility is part of the disruption portion of new laches. The language used by the Eastern District of New York in Shinnecock Indian Nation v. New York ${ }^{221}$ demonstrates the court's understanding that the defense used in these cases is new and not closely related to traditional laches. For example, the judge in Shinnecock stated that Cayuga "unveiled" three principles relating to laches and Indian land claims - that equitable defenses apply to disruptive claims, equitable defenses apply at law and equity, and equitable defenses can apply at the pleadings stage. ${ }^{222}$ The judge in Shinnecock concluded that these concepts were "unveiled."223 The word choice of "unveiled" is telling of a lack of supporting precedent other than Cayuga and Sherrill. Interestingly, the judge in Shinnecock also pointed out that the facts in City of Sherrill caused the Supreme Court to "initiate" the impossibility doctrine. ${ }^{224}$ While the Shinnecock court held against the tribe, the judge's language reveals an understanding of this defense as fundamentally different from precedent. The revealing of "new" doctrines and understanding of the law was done specifically to find against Indian land claims and is not used in any other area of law. This distinction recognizes the shaky basis on which City of Sherrill and its progeny were decided. Ultimately, these cases undermine the rule of law because they lead to only one conclusion; the new laches defense was created for one purpose - to defeat tribal claims. ${ }^{225}$

\footnotetext{
219

220

City of Sherrill, 544 U.S. at 218.

Id.

221 No. 05-CV-2887, 2006 WL 3501099 (E.D.N.Y. Nov. 28, 2006)

222 Id. at $* 4$

223 Id.

224 Id. at $* 5$.
}

225 See Cayuga Indian Nation v. Pataki, 413 F.3d 266, $275-76$ (2d Cir. 2005) ("Plaintiffs urge us to conclude that, as a legal remedy, ejectment is not subject to equitable defenses, relying, inter alia, on the Supreme Court's statement in Oneida II that 'application of the equitable defense of laches in an action at law would be novel indeed.' . . . One of the few incontestable propositions about this unusually complex and confusing area of law is that doctrines and categorizations applicable in other areas do not translate neatly to these claims. ... In light of the unusual considerations at play in this area of the law, and our agreement that ordinary common law principles are indeed 'not readily transferrable to this action,' we see no reason why the equitable principles identified by the Supreme Court in Sberril [sic] 
However, it may be possible to identify some distinct rules regarding new laches, especially as these rules conflict with maxims surrounding traditional laches. Traditional laches is about delay and injury; new laches is about delay and disruption. ${ }^{226}$ Traditional laches is an equitable defense; new laches is both a legal and equitable defense. ${ }^{227}$ Traditional laches requires an evaluation of the facts and "equities" of the case; new laches can apply at the pleadings stage. ${ }^{228}$ Traditional laches is generally not applied if a statute of limitations already is in place; new laches can (and will) apply within a statute of limitations. ${ }^{229}$ Traditional laches usually requires clean hands; new laches does not. ${ }^{230}$ Traditional laches does not usually apply to a sovereign; new laches has applied to sovereigns, but this question is open at the Supreme Court level and has only been discussed in one case. ${ }^{231}$ All of these distinctions demonstrate why countering a traditional laches argument has not worked for tribes.

\section{New Laches as Precedent in the Lower Federal Courts}

Understanding that the "laches" defense used in City of Sherrill and its progeny is related to traditional laches in name only is the key to facing this defense in federal courts. Arguments related to traditional laches have repeatedly failed in the Second Circuit. ${ }^{232}$ Given that precedent, it would seem unlikely that they will prevail elsewhere. This new laches is a combination of the Supreme Court's discussion of impossibility, acquiescence, and laches. ${ }^{233}$ Impossibility and acquiescence have their own difficult history, and later cases have combined them into one discussion of laches. These discussions in various opinions (almost all in the Second Circuit) lay out some major distinctions between laches and new laches.

should not apply to this case, whether or not it could be technically classified as an action at law." (citations omitted)).

226 Compare 30(A) C.J.S. Equity $\$ 147$ (2008), with City of Sherrill v. Oneida Indian Nation, 544 U.S. 197, 215 n.9, 219 (2005).

227 Compare 30A C.J.S. Equity $\$ 138$ (2007), with Cayuga, 413 F.3d at 276.

228 Compare 30A C.J.S. Equity \$ 142 (2007), with Shinnecock, 2006 WL 3501099, at *4.

229 Compare 30A C.J.S. Equity § 138, with Cayuga, 413 F.3d at 273.

230 Compare Pl.'s Mem. of Law in Opp'n to Defs.' Mot. to Dismiss at 17, Onondaga Nation v. New York, No. 05-CV-00314 (N.D.N.Y. Nov. 16, 2006) (arguing that, in a land claim case by the Onondaga Nation where the State of New York raised the defense of laches, New York did not come to court with clean hands as it acquired the land in dispute in violation of federal law), with 30A C.J.S. Equity $\$ 109$ (2007).

231 Compare Costello v. United States, 365 U.S. 265, 281 (1961) (collecting cases that hold that laches is not a defense against the sovereign), with City of Sherrill, 544 U.S. at 213-14.

232 See, e.g., Cayuga, 413 F.3d at 279.

233 See supra Part III.B. 
1. Definitional Change: Delay and Injury v. Delay and Disruption

There are many differences between new laches and traditional laches, but the most important is the difference in their basic definition. Traditional laches has two requirements: delay and injury or prejudice. ${ }^{234}$ New laches also has two requirements, but they are delay and disruption. ${ }^{235}$ Articles, testimony, and briefs have demonstrated that tribes did not delay in bringing their claim, that tribes were prevented from being heard in the courts, and that in working to bring their claim, the defendants were aware of these claims. ${ }^{236}$ As discussed earlier, the Rhode Island case demonstrates the proposition that when a party cannot avail itself of a court, laches should not apply to a delay. ${ }^{237}$ One author also notes that "defendants may not assert laches against a plaintiff whose delay is justified, even if the defendant is prejudiced by the delay." 238 Either of these statements would apply to most Indian land claims.

Rather than focusing on the equities of delay, the courts are instead focusing on the disruption to the current landowners. By the time the Second Circuit interpreted new laches in Cayuga, the land claims themselves were inherently "disruptive." ${ }^{239}$ Prejudice, on the other hand, requires a showing by the defendant of a change in circumstances such that the defendant is injured by the plaintiff bringing the claim late. ${ }^{240}$ While it can hardly be argued that the circumstances surrounding the land accounted for in most of the New York claims have not changed, there are multiple reasons why this is a specious argument. First, in City of Sherrill, the land in question, again, was held by the Nation. ${ }^{241}$ The defendants were not forced to argue what prejudice it would suffer by the exercise of tribal sovereignty. Second, in Cayuga, the Nation argued for two remedies, monetary damages or ejectment. ${ }^{242}$ The Nation continued arguing for the ejectment remedy because it felt the monetary award at the lower court level was not enough to compensate for the taking. ${ }^{243}$ The Second Circuit did not need to reach the discus-

23430 A C.J.S. Equity $§ 147$ (2008).

235 City of Sherrill, 544 U.S. at 215 n.9, 219; see also Cayuga, 413 F.3d at 277.

236 See, e.g., Pl.'s Mem. in Opp'n to Defs.' Mot. to Dismiss at 16-21, Onondaga Nation v. New York, No. 05-CV-00314 (N.D.N.Y. Nov. 16, 2006); Singer, supra note 4, at 627.

237 Rhode Island v. Massachusetts, 40 U.S. 233, 272 (1841).

238 Joseph Mack, Nullum Tempus: Governmental Immunity to Statutes of Limitation, Laches, and Statutes of Repose, 73 DEF. COUNS. J. 180, 183 (2006).

239 Cayuga, 413 F.3d at 277 ("“[D]isruptive,' forward-looking claims, a category exemplified by possessory land claims, are subject to equitable defenses, including laches.").

240 Thomas G. Robinson, Laches in Federal Substantive Law: Relation to Statute of Limitations, 56

B.U. L. REV. 970, 971-72 (1976).

241 City of Sherrill v. Oneida Indian Nation, 544 U.S. 197, 211-12 (2005)

242 Cayuga, 413 F.3d at 269.

243 Reply Brief of Appellees/Cross-Appellants Cayuga Indian Nation and Scneca Cayuga Tribe, 413 F.3d 266 (2005), 2003 WL 24300621 , at *1-2 (Nov. 11, 2003). 
sion of ejectment. The court could have affirmed or increased the district court's award of monetary relief, which would not be prejudicial to other landowners as it would not affect their ownership or title to the land. ${ }^{244} \mathrm{Fi}$ nally, as one commentator writes, laches "exacts of the plaintiff no more than fair dealing with his adversary." 245 The prejudice behind laches implies a plaintiff holding on to his claim until the defendant will certainly be injured by bringing the claim itself. ${ }^{246}$

Disruption, on the other hand, requires none of these things. Simply the bringing of the claim is disruptive. ${ }^{247}$ The defendant is not required to show how the claim will be prejudicial. The claim does not even have to touch the title of the landowners. Disruption, in other words, is a lower standard than prejudice.

Disruption also takes part of its definition under new laches from impossibility because, in the Supreme Court's circular reasoning, any disruption of current landowners would be impossible and thus disruptive. ${ }^{248}$ Disruption evokes images of innocent parties subject to forces beyond their control, forced off their land or otherwise "disrupting" their lifestyle. ${ }^{249}$ It implies that the exercise of tribal sovereignty is inherently disruptive rather than orderly. ${ }^{250} \mathrm{~A}$ fear of disruption weighs heavily in the courts, and the disruption of the current landowners has so far weighed more heavily than the inequities toward tribes, as shown by the almost universal losses by tribes when faced with new laches. ${ }^{251}$ Even demonstrating the tribe did not actually delay in bringing the claim has so far been futile against the court's

Cayuga, 413 F.3d at 272.

4 POMEROY, supra note $114, \S 1443$, at 3423

246 See 2 JOHN NORTON POMEROY, POMEROY'S EQUITY JURISPRUDENCE $§ 419$ (d), at 177 (Spencer Symons ed., Bancroft-Whitney Co. 1992).

247 Cayuga, 413 F.3d at 277 (“[T]he import of Sherrill is that 'disruptive,' forward-looking claims, a category exemplified by possessory land claims, are subject to equitable defenses, including laches.").

248 City of Sherrill v. Oneida Indian Nation, 544 U.S. 197, 219 (2005) ("[T]he unilateral reestablishment of present and future Indian sovereign control, even over land purchased at the market price, would have disruptive practical consequences similar to those that led this Court in Yankton Sioux to initiate the impossibility doctrine.").

249 Cayuga, 413 F.3d at 275 ("Under the Sherrill formulation, this type of possessory land claimseeking possession of a large swath of central New York State and the ejectment of tens of thousands of landowners-is indisputably disnuptive. Indeed, this disruptiveness is inherent in the claim itselfwhich asks this Court to overturn years of settled land ownership ...."); Ottawa Tribe v. Ohio Dep't of Natural Res., 541 F. Supp. 2d 971, 978 (N.D. Ohio 2008) ("Allowing Plaintiff to hunt and fish within these public lands would create a significant disruption for visitors to the state parks ....").

250 See City of Sherrill, 544 U.S. at 220 ("If OIN may unilaterally reassert sovereign control and remove these parcels from the local tax rolls, little would prevent the Tribe from initiating a new generation of litigation to free the parcels from local zoning or other regulatory controls that protect all landowners in the area."); Cayuga Indian Nation v. Vill. of Union Springs, 390 F. Supp. 2d 203, 206 (N.D.N.Y. 2005) ("If avoidance of taxation is disruptive, avoidance of complying with local zoning and land use laws is no less disruptive. In fact, it is even more disruptive.").

251 See supra Part I (discussing cases decided since City of Sherrill). 
perception of potential disruption in allowing the claim to proceed. ${ }^{252}$ This implies that the disruption prong of new laches is more important than the delay prong, dooming tribes that only argue against the delay aspect of new laches.

\section{Theoretical Change: Equitable Defense v. Legal Defense}

As discussed above, traditional laches is a product of the English courts of equity and was imported to U.S. courts through the constitutional clause allowing the Supreme Court to hear cases in both "law and equity." 253 It is true that the difference between the cases in law and cases in equity has blurred significantly. ${ }^{254}$ Federal courts never had separate equity and law courts, though there were separate rules of procedure for both until 1934. ${ }^{255}$ When law and equity merged, however, there still existed specific differences between claims brought in equity and claims brought in law. Applicable to this discussion is the general rule that equitable defenses can only be used against claims for equitable remedies. ${ }^{256}$ As the Supreme Court stated in County of Oneida (Oneida II), "application of the equitable defense of laches in an action at law would be novel indeed."257

"[A]bolishing the law-equity distinction," as one commentator noted, "may increase the risk that courts would treat [equitable] defenses as all-ornothing propositions." 258 Because using equity and equitable defenses still allows the plaintiff to bring a claim at law, barring the claim using an equitable defense was often not the end of the case. ${ }^{259}$ However, since new laches applies to legal claims as well as equitable claims, new laches becomes an all-or-nothing proposition, barring Indian land claims at the first whiff of disruption.

In City of Sherrill, the Oneida Indian Nation did not specifically request an equitable remedy. ${ }^{260}$ In their brief, the Nation wrote:

252 See supra text accompanying notes 236-49.

253

U.S. CONST. art. III, $\S 2$.

254 See 30A C.J.S. Equity § 8 (2007) (noting the Federal Rules of Civil Procedure "abolishe[d] the procedural distinctions between actions and the forms of actions at law and in equity, so that there is now only one form of civil action in the federal courts, and legal and equitable remedies may be administered in the same forum and in the same action").

255 Main, supra note 83, at 471 .

256 Shelby D. Green, Specific Relief for Ancient Deprivations of Property, 36 AKRON L. REV. 245, 280 (2003).

257 County of Oneida v. Oneida Indian Nation, 470 U.S. 226, 244 n.16 (1985).

258 Edward Yorio, A Defense of Equitable Defenses, 51 OHо ST. L.J. 1201, 1238 (1990).

259 Id. at 1240.

260 City of Sherrill v. Oneida Indian Nation, 544 U.S. 197, 211-12 (2005). 
In Oneida II, the Court left open whether "equitable considerations" might limit ejectment as a remedy with respect to land that is not in the Oneidas' possession. The issue here is not remedy for dispossession, but protection of actual possession accompanied by an unextinguished federally protected possessory right. ${ }^{261}$

However, the City of Sherrill Court characterized the Nation's claim as seeking "equitable relief prohibiting, currently and in the future, the imposition of property taxes." ${ }^{262}$ By framing the case in this manner, the Court was able to introduce equitable defenses into a legal claim.

Reframing the tribe's claim was not limited to the City of Sherrill decision. Other cases in the Second Circuit have been reframed from a legal to an equitable claim, even if the tribe expressly stated the claim was not equitable. ${ }^{263}$ This gives the courts the ability to apply "laches" (actually new laches) rather than focusing on the legal discussion. In Cayuga, the original claim for ejectment was also a legal remedy. ${ }^{264}$

\section{Application Change: Evaluating the Equities v. Summary Judgment}

Perhaps the most distressing aspect of new laches is the extent to which the court is willing to use it. Traditional laches requires a balancing of equities. ${ }^{265}$ As has been quoted previously, laches is not simply the passage of time. ${ }^{266}$ For example, in 1857, an English court held: "[m]ere lapse of time does not bar in equity any more than at law: it is an ingredient which, with other circumstances, may lead the Court to draw inferences unfavourable to the claim of a party who has let twenty or nearly twenty years elapse without asserting his right." ${ }^{267}$ Traditional laches is an elastic defense, which requires some work on the part of the defendant to demonstrate why the shield of laches should apply to him.

As noted above, in a boundary dispute between Rhode Island and Massachusetts, Rhode Island avoided dismissal of its claim based on laches

261 Brief for Respondents at 19, City of Sherrill v. Oneida Indian Nation, 544 U.S. 197 (2005) (No.

03-855) (citation omitted).

262 City of Sherrill, 544 U.S. at 212.

263 Cayuga Indian Nation v. Pataki, 413 F.3d 266, 274 (2d Cir. 2005).

264 Cayuga, 413 F.3d at 274, 276. In finding laches did apply to a legal claim, the Cayuga court used the "complexity" of federal Indian law against the tribe, stating that "[i]n light of the unusual considerations at play in this area of the law, and our agreement that ordinary common law principles are indeed 'not readily transferable to this action,' we see no reason why the equitable principles identified by the Supreme Court in Sberrill [sic] should not apply to this case, whether or not it could be technically classified as an action at law." Id.

265 See 30A C.J.S. Equity § 142 (2007).

267 Penny v. Allen, (1857) 7 De G.M. \& G. 409, 426, 44 Eng. Rep. 160, 166 (Ch.) 
because the state did not acquiesce to the boundary. ${ }^{268}$ The avoidance of dismissal was primarily based on the fact that laches should not be weighed on the pleadings. ${ }^{269}$ No plaintiff, particularly one specifically not arguing an equitable claim, would argue against laches. That would require the plaintiff to anticipate the defendant's laches defense, essentially forcing the plaintiff to plea the defendant's unclean hands. Because traditional laches requires a balancing of the equities and is deployed as a defense to a claim for equitable remedy, dismissing a claim at the 12(b)(6) stage simply ignores the basic requirements of laches. In doing this, the courts are using new laches, which can be dispatched at the earliest opportunity, because any forward movement on the case would bring "disruption" to the defendants. ${ }^{270}$

\section{Procedural Change: Statute of Limitations v. Discretionary Limits}

Historically, laches has been obedient to statutes of limitations; if a statute of limitations exists, laches must follow that time frame. ${ }^{271}$ In a case both highly cited and citing to Smith v. Clay, Lord Redesdale wrote, "I think it is a mistake in point of language to say that Courts of Equity act merely by analogy to the statutes; they act in obedience to them." ${ }^{\prime 27} \mathrm{He}$ went on to write:

I think, therefore, courts of equity are bound to yield obedience to the statute of limitations upon all legal titles and legal demands, and cannot act contrary to the spirit of its provisions. I think the statute must be taken virtually to include courts of equity; for when the legislature by statute limited the proceedings at law in certain cases, and provided no express limitations for proceedings in equity, it must be taken to have contemplated that equity followed the law, and therefore, it must be taken to have virtually enacted in the same cases a limitation for courts of equity also. ${ }^{273}$

268 See supra text accompanying notes $186-90$.

269 See Rhode Island v. Massachusetts, 40 U.S. (15 Pet.) 233, 273-74 (1841) (holding that the issue of whether the delay in bringing the complaint was justified could not be disposed of on the pleadings).

270 Pl.'s Mem. of Law in Opp'n to Defs.' Mot. to Dismiss at 3, Onondaga Nation v. State of New York, No. 05-CV-00314 (N.D.N.Y. Nov. 16, 2006) ('Fed. R. Civ. P. Rule 8(c) requires that affirmative defenses, such as laches, 'must be set forth affirmatively.' Further, Rule 12 requires that such affirmative defenses be raised in a pleading, not in a Rule 12(b) motion. Thus, the equitable defenses of laches, acquiescence and impossibility are not appropriate subjects for a Rule 12(b)(6) motion to dismiss, because they are fact-based, affirmative defenses that raise matters outside the complaint.").

271 DOBBS, supra note 43, at 77.

272 Hovenden v. Annesley, 2 Sch. \& Lef. 607, 629 (1806). See also Robinson, supra note 240, at 973-74 (claiming that the "federally developed laches doctrine applies only to those claims based upon federal equitable or maritime rights for which Congress has neglected to establish a limitations period" (emphasis added)).

273 Hovenden, 2 Sch. \& Lef. at 630. 
In the absence of a statute of limitations, courts of equity looked to analogous statutes and then weighed the equities. ${ }^{274}$ However, without a statute of limitations, mere length of time was not enough to invoke the laches defense. ${ }^{275}$ As one U.S. commenter wrote, "a thousand years in the sight of the Chancellor are but as yesterday." ${ }^{276}$ If the claim is a legal one and there is still no statute of limitations, laches will not apply because the claim is legal, not equitable. ${ }^{277}$

However, the courts have applied laches to legal Indian land claims, which are supposed to be governed by an applicable statute of limitations. ${ }^{278}$ The Indian Claims Limitation Act specifically states that no time bar will govern in cases "for bringing an action to establish the title to, or the right of possession of, real or personal property."279 As in other areas of Indian land claims, the courts apply new laches while ignoring both congressional intent and the rules surrounding laches. ${ }^{280}$

\section{Doctrinal Change: Clean Hands v. Illegal Actions}

A basic maxim in all of equitable jurisprudence, not just laches, is "he who comes into equity must come with clean hands." ${ }^{281}$ Unclean hands is an equitable defense, generally used against the plaintiff. ${ }^{282}$ However, as one author writes, "the point . . . is not that the plaintiff's unclean hands furnish a 'defense' to the defendant, but rather that the court itself wishes to avoid participating in iniquity." ${ }^{283}$ Unclean hands often refers to illegality or fraud associated with the claim the plaintiff brings, specifically if the plaintiff is "seeking to secure a benefit 'from the very conduct' which is inequitable." 284 In current tribal land claims, the tribes are often the plaintiffs, so that the plaintiffs would be put in the position of arguing the defense of

274 See Hedges v. Dixon County, 150 U.S. 182, 192 (1893); see also Heriot, supra note 65, at 953 ("In situations that require courts to apply the laches doctrine, they simply apply the period specified in the most analogous statute of limitations....").

275 See supra text accompanying note 110.

276 Pepper, supra note 2, at 331.

277 Green, supra note 256, at 280.

278 E.g., Cayuga Indian Nation v. Pataki, 413 F.3d 266, 273 (2d Cir. 2005).

27928 U.S.C. $\$ 2415$ (c) (2000).

280 See generally Philip P. Frickcy, Congressional Intent, Practical Reasoning, and the Dynamic Nature of Federal Indian Law, 78 CAL. L. REV. 1137, 1143 (1990) (examining four other areas of fedcral Indian law and concluding that "[i]n each area, reference to congressional intent does not support the results of the principal cases").

28121 C.J. $\$ 163(1920)$.

282 DoBBS, supra note 43 , at 68 .

284 Id. at 70. 
unclean hands of the defendant. ${ }^{285}$ However, it has been amply illustrated here that the traditional rules regarding equitable defenses and remedies have shifted dramatically. Both the City of Sherrill Court and the Cayuga court claimed to be evaluating these claims under "equitable considerations." ${ }^{286}$ Certainly the state defendants in these cases were looking to benefit from illegal and fraudulent activity. The land in question in the New York cases was all taken in violation of federal law, and usually under questionable circumstances. ${ }^{287}$ According to Professor Campisi, "[i]n 1788 and 1789 [New York] took by fraud and deceit over seven million acres of land, the largest amount from the Oneidas." ${ }^{288}$ For the state to benefit from an equitable defense given its illegal and certainly inequitable dealings with the tribes is "novel indeed." 289

However, courts using the new laches defense do not consider this aspect of the state's actions regarding the land claims. ${ }^{290}$ Again, simple delay, whether justified or not, and disruption weigh more heavily than other equities. This separation of equity from equitable defenses allows the courts to rule in favor of the non-tribal defendants regardless of their actions.

In new laches, the defendant's illegal actions do not weigh in the balancing of equities. While no court has discussed clean hands in the context of these claims, the state comes to these cases with unclean hands. ${ }^{291}$ Tribes continue to brief this in their memorandums of law, ${ }^{292}$ but thus far the courts have not considered them under new laches. Even in cases where the judge acknowledges the state's action and culpability, the court still applies new laches regardless of the wrong. ${ }^{293}$ Oddly, in most cases an action in violation of law, including the wrongful taking of land, does not become

285 E.g., City of Sherrill v. Oneida Indian Nation, 544 U.S. 197 (2005); Cayuga Indian Nation v. Pataki, 413 F.3d 266 (2d Cir. 2005); Cayuga Indian Nation v. Vill. of Union Springs, 390 F. Supp. 2d 203 (N.D.N.Y. 2005).

286 City of Sherrill, 544 U.S. at 217-20; Cayuga, 413 F.3d at 275.

287 Krakoff, supra note 31, at 12-13; Singer, supra note 4, at 612.

288 Jack Campisi, From Stanwix to Canandaigua: National Policy, States' Rights and Indian Land, in IRoQuois LaND Claims 49, 58 (Christopher Vecsey \& William A. Starna eds., 1988). Campisi goes on to give a specific example of the deception used by Governor Clinton and New York treaty commissioners to obtain five million acres of land for " $\$ 2,000$ in cash, $\$ 2,000$ in clothing, $\$ 1,000$ in provisions and $\$ 600$ in annual rental." Id. at 59. See also Singer, supra note 4, at 615 ("The state of New York ignored the Nonintercourse Act when it entered negotiations with the Oneida Indian Nation to take its remaining lands. Unprotected by the United States, the Oneida Nation was effectively compelled to relinquish more of its lands to the state of New York in violation of federal law.").

289 County of Oneida v. Oneida Indian Nation, 470 U.S. 226, 244 n.16 (1985)

290 See, e.g., Cayuga, 413 F.3d at 275-77; see also Krakoff, supra note 31, at 7-8, 12.

291 See supra notes 283-88 and accompanying text.

292 E.g., Pl.'s Mem. of Law in Opp'n to Defs.' Mot. to Dismiss at 17, Onondaga Nation v. State of New York, No. 05-CV-00314 (N.D.N.Y. Nov. 16, 2006).

293 See City of Sherrill v. Oneida Indian Nation, 544 U.S. 197, 216-17 \& n.11 (2005). 
legal simply by the passage of time. ${ }^{294}$ However, under new laches, the courts are only concerned about the current disruption to current landowners. ${ }^{295}$ An honest evaluation of past actions by the tribes and past actions by the state is never part of the opinion. This is fundamentally different from traditional laches, where the past weighs heavily on the determination of the claim.

\section{Sovereign Immunity from Laches}

The rest of this Part discusses the maxim of sovereign immunity from laches. Because this is one area where new laches is not fully settled, it is an area for tribes to focus on when faced with the defense. Sovereign immunity from laches is an area where the law is relatively clear in traditional laches and unclear in new laches. The City of Sherrill Court did not consider the issue and the Cayuga court discussed its application only as to the United States. ${ }^{296}$ Tribes should continue to argue that they are immune from laches, even after the Cayuga opinion. Tribal sovereign immunity is still a viable defense in federal courts, particularly if the case is tied to the tribe's inherent sovereignty. ${ }^{297}$ Given the similar roots between sovereign immunity from suit and sovereign immunity from laches, ${ }^{298}$ an argument drawing this parallel for tribal sovereign immunity from suit and from laches may be one way to counter new laches. As discussed below, sovereign immunity from laches is discussed in the Cayuga opinion, but is tenuously based on inapplicable court opinions. ${ }^{299}$

294 See, e.g., Causey v. United States, 240 U.S. 399, 402 (1916) ("And when a suit is brought to annul a [land] patent obtained in violation of these restrictions [on disposal of public lands], the purpose is not merely to regain the title, but also to enforce a public statute and maintain the policy underlying it. Such a suit is not within the reason of the ordinary rule that a vendor suing to annul a sale fraudulently induced must offer and be ready to return the consideration received. That rule, if applied, would tend to frustrate the policy of the public land laws; and so it is held that the wrongdoer must restore the title unlawfully obtained and abide the judgment of Congress as to whether the consideration paid shall be refunded.").

295 Cayuga, 413 F.3d at 274.

296 City of Sherrill, 544 U.S. at 217-20; Cayuga, 413 F.3d at 278-79.

297 Kiowa Tribe v. Mfg. Techs., Inc., 523 U.S. 751, 754-56 (1998). But see C \& L Enters., Inc. v. Citizen Band Potawatomi Indian Tribe, 532 U.S. 411, 418 (2001) (finding the tribe waived sovereign immunity); TTEA v. Ysleta del Sur Pueblo, 181 F.3d 676, 681 (5th Cir. 1999) (allowing a case to be brought against a tribe for injunctive relief, but holding on other grounds the tribal court retained jurisdiction over the case).

298 United States v. Thompson, 98 U.S. 486, 490 (1878) ("The exemption of the United States from suits, except as they themselves may provide, rests upon the same foundation as the rule of nullum tempus with respect to them.").

299

See Cayuga, 413 F.3d at 278-79. 


\section{The Original Understanding of Sovereign Immunity from} Equitable Defenses

Our legal notions of sovereignty, embodied in certain legal defenses such as sovereign immunity and immunity from laches, originate in the western, English understanding of the king and the law. Bracton referred to the king as vicarius Dei in terris, essentially, God's representative on earth. ${ }^{300}$ This understanding of the king led to certain doctrines that protected the role of the king as God's servant and protector of his subjects. ${ }^{301}$ Specifically relating to laches, the concept of nullum tempus occurrit regi, or that no time runs against the king, prevented the defense of laches from applying to the king. ${ }^{302}$ Because the king was the sovereign of the country and representative of his people, doing the people's business could not interfere with timely court claims. ${ }^{303}$ The king could do no wrong, and he was assumed to be permanently occupied with the people's business. ${ }^{304}$ Allowing the king to be subject to laches would be a direct contradiction of this legal understanding of sovereignty. Much like sovereign immunity, which protected the king from lawsuits, protection from laches originated ultimately from the understanding that any jurisdiction over the king would lessen his power. ${ }^{305}$ "[H] is supreme sovereignty makes him immediate under God . . . It makes all lands to be holden of him, every surrender unto him to be good, no action to lie against him, for who shall command the king?"306

Immunity from laches has also been linked to the understanding of sovereign immunity as far back as 1716 , and likely before. ${ }^{307}$ Because all justice flowed from the king and the king was the source of all law, equitable defenses such as laches, and later acquiescence, could not be then used against the king. The sovereign was immune from the defense of laches. ${ }^{308}$ This understanding carried over in Supreme Court decisions such as United States $v$. Kirkpatrick, ${ }^{309}$ perhaps the first case discussing the issue. The Court held that " $[t]$ he general principle is, that laches is not imputable to the

Fritz Schulz, Bracton on Kingship, 60 ENG. HIST. REV. 136, 149 (1945).

See T.A. MORRIS, EuRope AND ENGland IN THE SiXTEENTH CENTURY 10 (1998).

302 See WILLIAM BLACKSTONE, 1 COMMENTARIES *247 ("In farther pursuance of this principle, the law also determines that in the king can be no negligence, or laches, and therefore no delay will bar his right.").

303 See id.

304 Id. at *245 ("Besides the attribute of sovereignty, the law also ascribes to the king, in his political capacity, absolute perfection. The king can do no wrong .....').

305 Schulz, supra note 300, at 149; see also Herbert Barry, The King Can Do No Wrong, 11 VA. L. REV. 349, 353 (1925).

3062 SIR HENRY FINCH, LAW OR A DISCOURSE THEREOF 83 (1759).

307 Attorney Gen. v. Norstedt, (1716) 146 Eng. Rep. 203, 205 (Exch. Div.).

308 BLACKSTONE, supra note 302 , at $* 247$.

30922 U.S. 720 (1824). 
Government; and this maxim is founded, not in the notion of extraordinary prerogative, but upon a great public policy." 310

That public policy became the public interest doctrine, a democratic adaptation of nullum tempus. In a case decided by Judge Story for the state of Massachusetts before he became a Supreme Court Justice, he discussed the adoption of nullum tempus in the United States. ${ }^{311}$ He surveyed English law and English commentators and ended with this conclusion:

\begin{abstract}
The true reason ... there can be no negligence or laches imputed to the crown, and, therefore, no delay should bar its right, though sometimes asserted to be, because the king is always busied for the public good, and therefore, has not the leisure to assert his right within the times limited to subjects .... 312
\end{abstract}

He went on to hold that this understanding of nullum tempus is "to be found in the great public policy of preserving the public rights, revenues and property from injury and loss, by the negligence of public officers ..." and is "introduced for the public benefit, and equally applicable to all governments." ${ }^{13}$ Accordingly, as the courts refined ideas of sovereign immunity from laches, they began to characterize this public policy as a public interest doctrine. ${ }^{314}$ In 1840, the Supreme Court held:

\footnotetext{
Not upon any notion of prerogative; for even in England, where the doctrine is stated under the head of prerogative this, in effect, means nothing more than that this exception is made from the statute, for the public good; and the king represents the nation. The real ground is a great principle of public policy, which belongs alike to all governments, that the public interest should not be prejudiced by the negligence of public officers . . . 315
}

The public right or public interest doctrine is based on the government's role to protect public interests or enforce public rights. ${ }^{316}$ To avoid laches, the sovereign must be protecting some public interest. ${ }^{317}$ Using this doctrine to keep laches from applying to a government in a case does provide a court with some leeway, allowing laches to attach if the government is protecting a private right. These cases are rare, but tend to be used in land title cases, when the current owner is trying to quiet title, and the original deed to the land came from the government. ${ }^{318}$ These cases tend to be older,

\footnotetext{
310 Id. at 735.

311 United States v. Hoar, 26 F. Cas. 329, 330 (C.C.D. Mass. 1821) (No. 15,373).

$312 \mathrm{Id}$.

313 Id.

314 See Green, supra note 256, at 282.

315 United States v. Knight, 39 U.S. 301, 315 (1840).

316 Green, supra note 256 , at 282.

317 27A AM. JUR. 2D Equity $\$ 121$ (2008).

318 E.g., United States v. Beebe, 127 U.S. 338, 343 (1888); United States v. Fletcher, 242 F. 818 , 820 (8th Cir. 1917) ("While the United States is not barred by laches from maintaining a suit brought to
} 
because outside of Indian law rarely does a quiet title action now trace its way back to the original government land grant.

For example, in United States $v$. Thompson, ${ }^{319}$ the Court stated that nullum tempus is an "incident[] . . o of sovereignty," held by each state and the United States after independence. ${ }^{320}$ The "exception [is] equally applicable to all governments." 321 This same statement was upheld by the Court in 1938 in Guaranty Trust Co. v. New York, ${ }^{322}$ when it added that this immunity is supportable "[r]egardless of the form of government and independently of royal prerogative once thought to justify it." ${ }^{323}$ As late as 1991, the Court stated "laches ... is generally inapplicable against a state." 324 Any sovereign, therefore, ought to be immune from the defense of laches. The public interest doctrine can also be broad, incorporating everything from state medical licensing boards ${ }^{325}$ to the collection of debts. ${ }^{326}$ Anything that can qualify as beneficial to a sovereign's citizens can fall under the public interest doctrine. ${ }^{327}$ If the sovereign is acting on behalf of its people when bringing a claim, any delay in that claim ought to be excused.

Similarly, the Supreme Court has held that acquiescence, like laches, cannot be applied against the federal government. ${ }^{328}$ In a dispute with the State of California over a three-mile belt of ocean off the coast of the state, the Court held that "officers who have no authority at all to dispose of government property cannot by their conduct cause the government to lose its valuable rights by their acquiescence, laches, or failure to act." ${ }^{329}$ More importantly, the officers with "no authority" worked at the Department of the Interior, where they denied oil and gas permits because they believed the land was owned by California. ${ }^{330}$ The Court held otherwise and the officials' actions were not enough to overcome the federal government's own-

enforce a public right or to assert a public interest, and in which it is the real party in interest, it is so barred from maintaining suits in which it is merely a formal party, brought to enforce the rights of individuals and involving no interest of the government. This distinction has often been declared in suits brought in the name of the United States to cancel grants of the public lands." (citing United States v. Beebe, 127 U.S. $338(1888))$ ).

31998 U.S. $486(1878)$.

320 Id. at 489.

321 Id. at 490 (citing United States v. Hoar, 26 F. Cas. 329, 330 (C.C.D. Mass. 1821) (No. 15,373)).

322304 U.S. 126 (1938).

323 Id. at 132.

324 Illinois v. Kentucky, 500 U.S. 380, 388 (1991).

325 Stein v. State Psychology Examining Bd., 668 N.W.2d 112, 116 (Wis. Ct. App. 2003).

326 See Oregon v. Ingram, 63 F.2d 417, 418 (9th Cir. 1933).

327 See 30A C.J.S. Equity $\S 141$ (2008).

328 United States v. California, 332 U.S. 19, 40 (1947).

329 Id. (citing United States v. City \& County of San Francisco, 310 U.S. 16, 31, 32 (1940); Utah v. United States, 284 U.S. 534, 545, 546 (1932); Lee Wilson \& Co. v. United States, 245 U.S. 24, 32 (1917); Utah Power \& Light Co. v. United States, 243 U.S. 389, 409 (1917)).

330 Id. at 39. 
ership. ${ }^{331}$ Seven years earlier, in a dispute with the city of San Francisco, the Court found that the "United States is neither bound nor estoppped by acts of its officers or agents in entering into an arrangement or agreement to do or cause to be done what the law does not sanction or permit." ${ }^{332}$ Again, the actions and agreements were those of the Department of the Interior. ${ }^{333}$

\section{State Sovereign Immunity from Laches}

In addition to a long federal history of sovereign immunity from laches, most states have a history of similar holdings. ${ }^{334}$ Much like sovereign immunity from suit, sovereign immunity from laches applies to sovereigns, but not lesser organized governments such as cities or municipalities. ${ }^{335}$

In a survey of state cases, only six states have expressly overturned the doctrine of nullum tempus. ${ }^{336}$ A majority of state courts consider the state government immune from laches. ${ }^{337}$ As early as 1840, a Supreme Court case found that the principle had "been decided in New York, Massachusetts, Pennsylvania, and no doubt, in other states . . .." ${ }^{938}$ Much like the application of sovereign immunity, some states have found that nullum tempus only applies to the state and does not apply to municipalities, ${ }^{339}$ highway boards, ${ }^{340}$ licensing boards, ${ }^{341}$ or cities. ${ }^{342}$ In at least one case, a

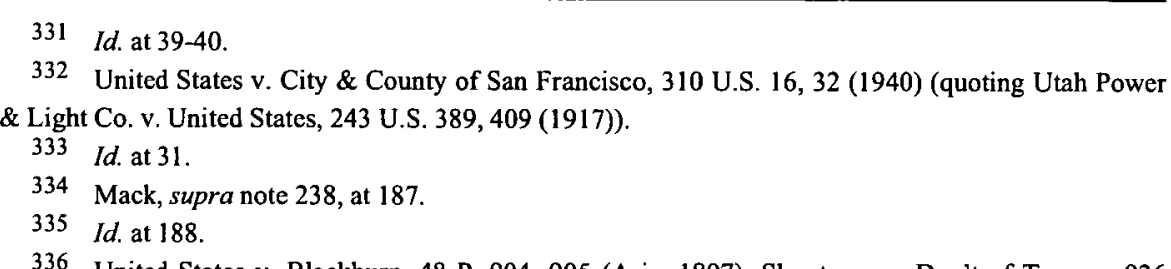

336 United States v. Blackburn, 48 P. 904, 905 (Ariz. 1897); Shootman v. Dep't of Transp., 926 P.2d 1200, 1206 (Colo. 1996) (en banc); Michigan Dep't of Treasury, Revenue Div. v. Campbell, 309 N.W.2d 668, 672-73 (Mich. Ct. App. 1981); New Jersey Educ. Facilities Auth. v. Gruzen P'ship, 592 A.2d 559, 561 (N.J. 1991) (with relation to statutes of limitations); Weinberg v. State Bd. of Exam'rs, 501 A.2d 239, 245 (Pa. 1985); State ex rel. Condon v. City of Columbia, 528 S.E.2d 408, $412-13$ (S.C. 2000). See also Sigmund D. Schutz, Time to Reconsider Nullum Tempus Occurrit Regi-The Applicability of Statutes of Limitations Against the State of Maine in Civil Actions, 55 ME. L. REV. 373, 375 (2003).

337 See, e.g., Guar. Trust Co. v. United States, 304 U.S. 126, 133 (1938) ("So complete has been its acceptance that the implied immunity of the domestic 'sovcreign,' state or national, has been universally deemed to be an exception to local statutes of limitations . . ." (citing United States v. Thompson, 98 U.S. 486, 489 (1878))); Brown v. Tr. of Sch., 79 N.E. 579, 579-80 (Ill. 1906); State v. Sch. Dist. No. 3 , 8 P. 208, 212 (Kan. 1885); Larocca v. State Bd., 897 S.W.2d 37, 45 (Mo. Ct. App. 1995); Dep't of Transp. v. J.W. Bishop \& Co., Inc., 439 A.2d 101, 101 (Pa. 1981).

338 United States v. Knight, 39 U.S. 301,315 (1840).

339 Royal Oak Twp. v. Sch. Dist. No. 7, 33 N.W.2d 908, 911 (Mich. 1948) (applying laches to a municipal corporation).

340 Dalton Highway Dist. of Kootenai County v. Sowder, 401 P.2d 813, 815 (Idaho 1965) (applying equitable estoppel to a county highway district). 
state that rejects state sovereign immunity from laches still requires a stronger showing of laches when suing the state than would be required for a private individual. ${ }^{343}$

Three examples from New York, Illinois, and Oregon demonstrate the majority view of the law in the United States regarding sovereign immunity from laches. In New York State from 1881 to 2004, state courts consistently found that laches did not apply to state actions, with one exception. ${ }^{344}$ In a 1995 case where the state Attorney General entered a money judgment six years after "entry of the judgment holding respondents liable for restitution to its defrauded customers," the New York Supreme Court Appellate Division let the money judgment stand, holding that " $[\mathrm{t}] \mathrm{he}$ doctrine of laches does not apply to the State when it acts in a governmental, as opposed to private or proprietary, capacity to enforce a public right or protect a public interest." 345

In Illinois, an 1873 case, which has not been overturned, held that it "is well settled that no laches can be imputed to the government, and by the same reasoning which excuses it from laches, and on the same grounds, it should not be affected by the negligence or even willfulness of any one of its officials." 346

Finally, in 1968, the Oregon Supreme Court surveyed state and federal cases on the issue and held that laches did not apply to the State Land Board and asserted that this was the majority view. ${ }^{347}$ This holding has been cited with approval in Oregon since. ${ }^{348}$

341 Shah v. State Bd. of Med., 589 A.2d 783, 800-04 (Pa. Comm. Ct. 1991). But see Stein v. State Psychology Examining Bd., 668 N.W.2d 112, 114-16 (Wis. Ct. App. 2003) (holding laches did not apply to a psychology examining board).

342 Boise City v. Wilkinson, 102 P. 148, 156-57 (Idaho 1909) (Ailshie, J., concurring) (applying laches to a city).

343 Weinberg v. Pennsylvania State Bd. of Exam'r of Pub. Accountants, 501 A.2d 239, 243 (Pa. 1985).

344 See Carney v. Newburgh Park Motors, 444 N.Y.S.2d 220, 221 (N.Y. App. Div. 1981) (applying laches to the State Insurance Fund because "[w]hile the State Insurance Fund is an agency of the State, its function is akin to that of a private insurance carrier ...").

345 New York v. Astro Shuttle Arcades, Inc., 633 N.Y.S.2d 304, 305 (N.Y. App. Div. 1995) (citing Carney, 444 N.Y.S.2d at 220-21).

346 People v. Brown, 67 Ill. 435, 438 (1873). See also State v. Platte Valley Pub. Power \& Irrigation Dist., 10 N.W.2d 631, 633-34 (Neb. 1943).

347 Corvallis Sand \& Gravel Co. v. State Land Bd., 439 P.2d 575, 578-84 (Or. 1968).

348 See, e.g., Shasta View Irrigation Dist. v. Amoco Chem. Corp., 986 P.2d 536, 55 ! (Or. 1999); DeFazio v. Washington Pub. Power Supply Sys., 679 P.2d 1316, 1347-48 (Or. 1984). 


\section{The Problem with Cayuga and Sovereign Immunity from Laches}

The Supreme Court has consistently held that laches does not generally apply to a sovereign. ${ }^{349}$ The City of Sherrill Court did not directly address this issue. However, the Court was applying laches to not one, but two sovereigns-the United States federal government and the Oneida Indian Nation government. ${ }^{350}$ The Cayuga court attempted to address this issue in its opinion, though the cases it cited were odd choices and were well addressed in the dissent. ${ }^{351}$ In particular, the Cayuga court specifically held that laches can apply to not only the sovereign Cayuga Nation, but to the United States government as well. ${ }^{352}$ In addition to the other problematic parts of this opinion, the application of laches to the United States is a rare occurrence, much less in a land claim situation.

The Cayuga court mentioned two cases, ${ }^{353}$ United States v. Administrative Enterprises, Inc. ${ }^{354}$ and National Labor Relations Board v. $P^{*} I^{*} E$ Nationwide, ${ }^{355}$ both opinions by Judge Posner. In these cases, the Seventh Circuit used three Supreme Court opinions to make the startling conclusion that "laches is generally and we think correctly assumed to be applicable to suits by government agencies as well as by private parties." 356

In $P^{*} I^{*} E$ Nationwide, a case involving the National Labor Relations Board, the court addressed whether laches would apply to the Board due to its delay in bringing an enforcement action for an unfair labor practice order. ${ }^{357}$ While the court ultimately held that laches did not apply to the National Labor Relations Board, the court acknowledged the view "that laches was not a defense to a suit by the United States," citing an 1888 Supreme Court case. ${ }^{358}$ However, the Seventh Circuit neglected to mention more recent cases in which the Supreme Court adopted this view, as recently as 1961. ${ }^{359}$ Yet, Judge Posner seemed ready to apply laches, but for the harm prong of the defense. ${ }^{360}$ Because no one was harmed by the delay in the

349 See, e.g., Costello v. United States, 365 U.S. 265, 281 (1961); United States v. Kirkpatrick, 22 U.S. (9 Wheat.) 720, 735 (1824).

350 See City of Sherrill v. Oneida Indian Nation, 544 U.S. 197, 213, 217 (2005).

351 See Cayuga Indian Nation v. Pataki, 413 F.3d 266, 278-79 (2005); id. at 286-89 (Hall, J., dissenting in part and concurring in the judgment).

352 Id. at 279.

353 Id. at $278-79$.

35446 F.3d 670 (7th Cir. 1995).

355894 F.2d 887 ( 7 th Cir. 1990).

356 Id. at 894 (citing EEOC v. Vucitech, 842 F.2d 936, 942 (7th Cir. 1988)); see Admin. Enters., Inc., 46 F.3d at 672-73 (citing $P^{*} I^{*} E$ Nationwide, Inc., 894 F.2d at 893-94; Vucitech, 842 F.2d at $942-$ 43). 
case, the court held laches would not apply against the National Labor Relations Board. ${ }^{361}$

United States v. Administrative Enterprises, decided five years later, goes further in its discussion of laches by seeking to interpret Occidental Life Insurance Co. v. EEOC, ${ }^{362}$ a case where the Supreme Court may have opened the door for the application of laches to the United States. ${ }^{363}$ Oddly, the Occidental Life case is not about laches, but about a statute of limitations, or lack thereof. ${ }^{364}$ The Occidental Life Court held that importing a state statute of limitations into the case would be "inconsistent with the congressional intent underlying the enactment of the 1972 amendments [to Title VII]." 365 The case began when the EEOC launched an investigation of Occidental Life that eventually led to an EEOC enforcement action. ${ }^{366}$ The company moved to have the action dismissed because the EEOC had exceeded a state statute of limitations. ${ }^{367}$

In finding against the company, the Supreme Court refused to apply the statute of limitations, stating that in future cases, the EEOC may delay too long in bringing an enforcement action. ${ }^{368}$ The Court held: "[i]f such cases arise the federal courts do not lack the power to provide relief. . . . The same discretionary power "to locate "a just result" in light of the circumstances peculiar to the case,' can also be exercised when the EEOC is a plaintiff." ${ }^{369}$ In the dissent, Justice Rehnquist argued for imposing a deadline on the EEOC, but made a distinction between the United States suing "in its sovereign capacity" and an enforcement suit from the EEOC. ${ }^{370} \mathrm{Re}-$ ferring to Board of County Commissioners of Jackson County v. United States, ${ }^{371}$ a federal Indian law case, Justice Rehnquist found this case inapplicable to the case at hand because "[i]t involved a suit brought by the United States in its sovereign capacity, to which it is clear state limitations period do not apply." ${ }^{372}$

The Administrative Enterprises opinion acknowledged that " $[\mathrm{t}] \mathrm{here}$ is no dearth of statements that laches cannot be used against the govern-

\footnotetext{
361 Id.

362432 U.S. 355 (1977).

363 See id.; United States v. Admin. Enters., Inc., 46 F.3d 670, 672-73 (7th Cir. 1995).

364 Occidental Life, 432 U.S. at 360-61.

365 Id. at 369.

366 Id. at $357-58$.

367 Id. at 358.

368 Id. at 376.

$369 I d$ at 373 (internal citation omitted) (quoting Albemarle Paper Co. v. Moody, 422 U.S. 405 , 424 (1975)).

370 Occidental Life, 432 U.S. at 374-75 (Rehnquist, J., dissenting).

371 Board of Comm'rs v. United States, 308 U.S. 343 (1939).

372 Occidental Life, 432 U.S. at 378 (Rehnquist, J., dissenting) (citing Board of Comm 'rs, 308 U.S. at 351).
} 
ment." ${ }^{373}$ However, the court went on to discuss the ways the door has been kept open on the question, specifically citing $P^{*} I^{*} E$ Nationwide. ${ }^{374}$ The court also mentioned that perhaps laches would only apply to the government in "egregious instances," or when there is no applicable statute of limitations, or if the government is looking to enforce a "private right." ${ }^{375}$ All of this is dicta, however, because the court then stated, "[w]e need not pursue the question of the existence and scope of a defense of laches in government suits to resolve this case." ${ }^{1376}$ On other grounds, the court found for the government. ${ }^{377}$ While these cases do not apply laches to the government, the Seventh Circuit's dicta on when laches may or may not apply to the government gave the Second Circuit needed ammunition for its argument that laches can now apply to the government. ${ }^{378}$ To the contrary, as illustrated above, there is a long history of the Supreme Court, lower courts, state courts, and commentators all agreeing that laches does not apply to a sovereign. ${ }^{379}$ At the very least, laches does not apply when a sovereign is enforcing a public right or protecting a public interest, nor does the laches of its agents bind a sovereign. ${ }^{380}$

The two other cases the Cayuga court cited are Supreme Court cases, Heckler v. Community Health Services of Crawford County, Inc. ${ }^{381}$ and Irwin v. Department of Veterans Affairs. ${ }^{382}$ Heckler is concerned with estoppel against the government, not laches. ${ }^{383}$ The Heckler Court stated that "it is well settled that the Government may not be estopped on the same terms as any other litigant." ${ }^{\text {"384 }}$ The Court went on to state that it was "hesitant" to hold that there "are no cases in which the public interest in ensuring that the Government can enforce the law free from estoppel might be outweighed by the countervailing interest of citizens in some minimum standard of decency, honor, and reliability in their dealings with their Government." 385 The Court did not reach this decision because it was "unnecessary to decide" the case. ${ }^{386}$ Irwin is another EEOC case concerned with equitable

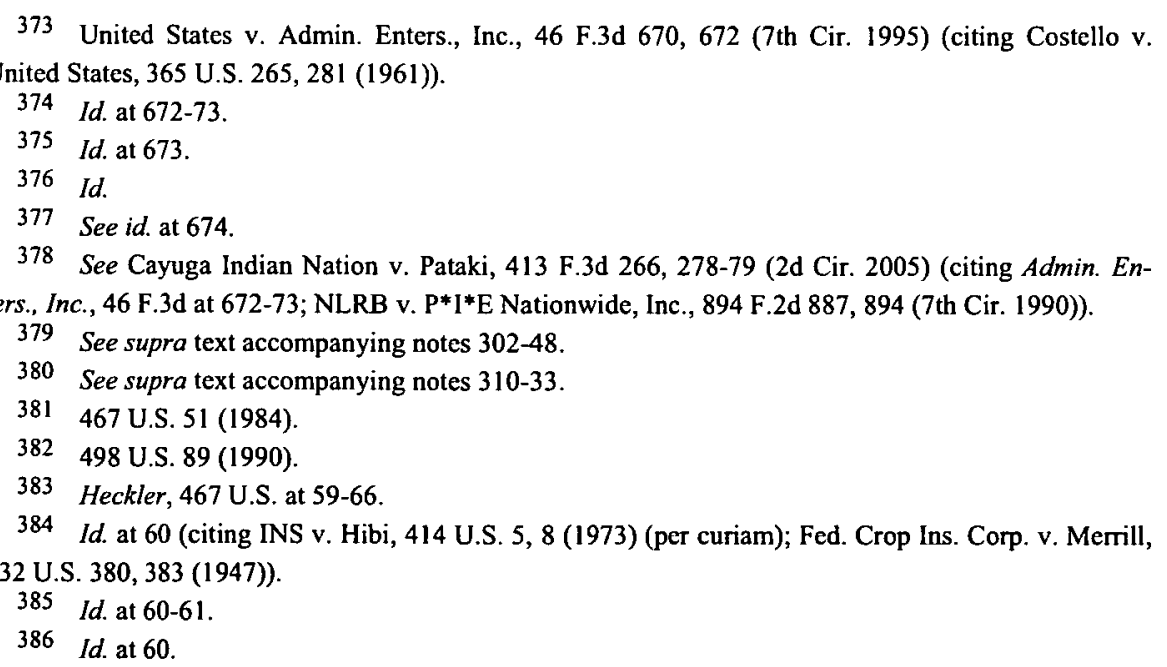


tolling, not laches. ${ }^{387}$ While the Court did state that "making the rule of equitable tolling applicable to suits against the Government, in the same way that it is applicable to private suits," ${ }^{888}$ would be appropriate, the key provision is the qualification at the beginning of that sentence: "[o]nce Congress has made such a waiver [of sovereign immunity]." "I89 In short, equitable tolling could only apply to the government when Congress has made an express waiver of sovereign immunity. ${ }^{390}$

The Cayuga court made the broad assertion that the Cayuga Nation land claim did not involve a public right or public interest and that the United States was therefore somehow not serving in its sovereign capacity. ${ }^{391}$ Given that the role of the United States in this case was the trustee for the tribe, and that the reason for the case in the first place was the exclusive role the United States government had in dealing with Indian tribes, it seems odd that bringing a land case with an Indian tribe would not be an express exercise of its sovereignty. The Cayuga case took the three exceptions from dicta in Administrative Enterprises and found an "egregious" case of laches, despite a statute of limitations that the court deemed did not apply because the United States was not acting as a sovereign in this particular case. ${ }^{392}$ Given the clear precedent holding otherwise, sovereign immunity from laches may still be an open question in the other circuits and practitioners should look at it as a possible defense to claims of new laches.

\section{Possible Implications of Arguing for Sovereign Immunity from Laches by Both Tribes and the Federal Government}

While a few cases have weighed the equities of an individual versus the government, ${ }^{393}$ no court has explicitly addressed when two sovereigns' public rights and interests come into conflict. While the Supreme Court has addressed state boundary disputes using the equitable defense of acquies-

Id. at 95 .

389 Id.

390 Id. at 95-96 (stating that a waiver of sovereign immunity "cannot be implied but must be unequivocally expressed" (quoting United States v. Mitchell, 445 U.S. 535, $538(1980)$ )). This is the same standard required for a waiver of tribal sovereign immunity.

391 See Cayuga Indian Nation v. Pataki, 413 F.3d 266, $279 \&$ n.8 (2d Cir. 2005) (distinguishing United States v. Angell, 292 F.3d 333, 338 (2d Cir. 2002)).

392 Id. at 278-79.

393 E.g., United States v. Verdier, 164 U.S. 213, 219 (1896) (stating that "the equities which arise as between individuals have but a limited application as between the government and a citizen" because the government is enforcing a public policy). See also Rhode Island v. Massachusetts, 40 U.S. (15 Pet.) 233, 273 (1841) (explaining that laches did not bar the claim because "here two political communitics are concerned, who cannot act with the same promptness as individuals"). 
cence, there has not been a weighing of public rights. ${ }^{394}$ The City of Sherrill Court placed the public rights as represented by the city and state higher than those represented by the tribe or the federal government. ${ }^{395}$ While this is not expressly stated anywhere in the opinion, it is apparent in the outcome.

Perhaps by getting the court to determine the relative value of public rights, a more honest evaluation of the equities of a land claim will be performed. Rather than framing the argument over the prongs of laches, the argument is between the public rights of the tribal citizens and of the state. How would these be weighed? Might a court engage in a clean hands analysis at that point, or otherwise concern itself with the ramifications of a laches defense against a sovereign? The courts generally gloss over exactly what a public right is, but needless to say, if a sovereign is suing on a public right, that sovereign is not subject to laches. Other defenses may apply, but getting past laches is a vital first step for any tribe in the post-City of Sherrill environment.

While one of the aspects of different Indian land claims cases now includes proof of constant attempts to settle the claim, which counters one prong of laches (that the plaintiff did not delay in bringing the claim), a tribe in its sovereign capacity should not even be required to argue that aspect. In countering an equitable defense, particularly laches, the tribe should use a multi-prong argument. This argument should begin with the claim that laches does not apply to sovereigns. The tribe is a sovereign, enforcing the public right of its citizens to its land, and laches cannot apply to them. Indeed, the tribe should not have to prove any constant attempt to bring the claim, because even if tribal leaders had not, the tribal citizens, as members of a sovereign entity, should not be harmed by the actions of past tribal leaders. In bringing the land claim, the tribe is simply protecting the public interest of its citizens.

The main problem, however, with the defense of new laches is the second prong - that the defendant will be disrupted as a result of the delay of the plaintiff. This will always weigh heavily in the federal courts; it is easy for the defendants in these cases to argue disruption if the title to the land is returned to the tribes. On the other hand, it is difficult for a tribe to demonstrate to the court's satisfaction that the tribe did not delay in bringing the claim. ${ }^{396}$ In order to do so, it must bring in historians and cite to old statutes and difficult case law. In addition, in new laches, a tribe must do so in its pleadings, lest the claim be dismissed at summary judgment.

Nonetheless, any statement that demonstrates laches is more than just the passage of time is important for tribes to have at their disposal. In regards to the second prong, the state may simply argue it has taxed the land

96 See supra note 236 and accompanying text. 
for two hundred years, that its citizens have lived on the land for two hundred years, and to disturb the title at this point would lead to disruption. Tribes must continue to point out the many contradictions. For example, a polluter does not get to keep polluting just because he has done it for a long time without the government noticing and suing. ${ }^{397}$ A law deemed to be unconstitutional does not get to be constitutional just because it has been on the books for a long time ${ }^{398}$ Length of time does not always ensure a right. In some states, misbehavior on the part of a physician or lawyer does not prevent the state from taking the professional license if a great deal of time has passed between the misbehavior and the disciplinary proceeding. ${ }^{399}$ Laches does not become an exemption for bad behavior.

For example, in a case from 1891, bona fide purchasers of land from a company that was supposed to build a road on the land were not "entitled to rely upon the acts of Congress of 1867 and 1874, the act of the state of Oregon, the certificate of the governor of that state, the withdrawal of the lands from sale, and the issue of the patent" because of the apparent fraudulent activities of the company (and perhaps the state) against the federal government. ${ }^{400}$ The Court also refused to allow the current land holders to argue laches against the government, nor would allow laches to apply at the pleading stage. ${ }^{401}$

Finally, applying laches against a sovereign opens the sovereign up to adverse possession claims and other liabilities stemming from delay in bringing cases on behalf of tribes. The Supreme Court recognized that by allowing a private party to win on the issue of laches in a land case meant that a private party could obtain title through adverse possession against the United States. ${ }^{402}$ In addition, at least one commenter has pointed out the possible effect of new laches on land claims preserved by the federal government. ${ }^{403}$

397 Even though Pennsylvania does not recognize state sovereign immunity from laches, the court did hold that "stream polluters can acquire no prescriptive or property right to pollute as against the Commonwealth no matter how long their conduct had been tolerated." Commonwealth v. Barnes \& Tucker Co., 319 A.2d 871, 883-84 (Pa. 1974) (citing Commonwealth ex rel. Shumaker v. N.Y. \& Pa. Co., 79 A.2d 439, 444 (Pa. 1951); Pa. R.R. v. Sagamore Coal Co., 126 A. 386 (Pa. 1924)).

398 Sears v. Treasurer \& Receiver Gen., 98 N.E.2d 621, 632 (Mass. 1951) ("An unconstitutional law cannot be made valid by the laches of anyone or by any lapse of time." (citing Banney \& Carey Co. v. Town of Milton, 87 N.E.2d 9 (Mass. 1949); Commonwealth v. Parker, 2 Pick. 550 (Mass. 1824))).

399 See Stein v. State Psychology Examining Bd., 668 N.W.2d 112, 114-17 (Wis. Ct. App. 2003).

400 United States v. Dalles Military Rd. Co., 140 U.S. 599, 615-16 (1891).

401 Id. at 632.

402 Lindsey v. Miller, 31 U.S. 666, 673 (1832) ("If a contrary rule were sanctioned, it would only be necessary for intruders upon the public lands, to maintain their possessions, until the statute of limitations shall run; and then they would become invested with title against the government, and all persons claiming under it. In this way the public domain would soon be appropriated by adventurers.").

403 See Matthew L.M. Fletcher, The Land-Claims Time Bomb, INDIAN COUNTRY TODAY, Jan. 19, 2007, http://works.bepress.com/matthew_fletcher/11/. 


\section{CONCLUSION}

Laches, an ancient defense from the courts of equity, now has new life in the courts of Indian land claims. However, the new laches, created by the Supreme Court to avoid regulatory disruption and expanded by lower courts to avoid all tribal land claims, bears little resemblance to the original defense. Traditional laches is defined by delay and injury; in a tribal land claim, the definition is delay and disruption. ${ }^{404}$ Traditional laches is an equitable defense; in a tribal land claim, it applies to both legal and equitable claims. ${ }^{405}$ Traditional laches requires an evaluation of the facts and balancing of equity; in a tribal land claim, new laches can apply as early as the pleadings stage. ${ }^{406}$ Traditional laches is usually not applied if a statute of limitations is in place; in a tribal land claim, it can (and will) apply within the applicable statute of limitations. ${ }^{407}$ Traditional laches usually requires clean hands; in a tribal land claim, it does not. ${ }^{408}$ The only way this defense now makes sense is as a new defense, a new laches. New laches has not replaced traditional laches as an available defense in all claims. So far, new laches only applies to Indian tribes. ${ }^{409}$

Defending against this new defense is difficult for tribes, particularly as courts continue to define its contours. Attacking the delay prong has so far proven relatively useless. ${ }^{410}$ Either finding a hole in the defense or attacking the disruption prong may prove to be one way to counter laches. Countering the disruption prong by demonstrating the lack of regulatory disruption the claim will cause may provide a strategy for tribes before ending up in federal court. However, one hole in the defense, that traditional laches does not usually apply to a sovereign, is explored extensively in this article. ${ }^{411}$ Tribal sovereign immunity from new laches is still an open question, and one for tribes to explore.

A vast majority of states and the federal government recognize that laches does not, in fact, apply to a state or federal government claim. The courts have long held that tribes are not subject to claims without their consent. ${ }^{412}$ The defense of laches should not run against tribes as sovereigns, and the link between laches and sovereign immunity should be perhaps made clear. Unfortunately, the litigation on laches is moving faster than the

\footnotetext{
404 See supra Parts II, III.C.1.

405 See supra Parts II, III.C.2.

406 See supra Parts II, III.C.3.

407 See supra Parts II, III.C.4.

408 See supra Parts II, III.C.5.

409 See supra Parts III.B-D.

410 See supra Part III.C.1.

411 See supra Part III.D.
}

412 Puyallup Tribe, Inc. v. Dep't of Game, 433 U.S. 165, 172 (1977) ("Absent an effective waiver or consent, it is settled that a state court may not exercise jurisdiction over a recognized Indian tribe."). 
research. This seems to be because courts, at least in the Second Circuit, may feel that they have a magic bullet in applying new laches because it will automatically eliminate all land claims. Whether sovereign immunity from new laches is possible is debatable. However, as federal courts continue to change the rules as tribes bring their land claims, reinforcing that these claims are an exercise of tribal sovereignty demonstrates the tribes' continued willingness to fight long and hard battles on an uneven and ever changing playing field. 
HeinOnline -- 16 Geo. Mason L. Rev. 402 2008-2009 